S. Riechelmann, S. F. M. Breitenbach, A. Schröder-Ritzrau, A. Mangini, and A. Immenhauser. Ventilation and cave air $P \mathrm{CO}_{2}$ in the Bunker-Emst Cave System (NW Germany): implications for speleothem proxy data. Journal of Cave and Karst Studies, v. 81, no. 2, p. 98-112. DOI:10.4311/2018ES0110

\title{
VENTILATION AND CAVE AIR PCO IN THE BUNKER-EMST CAVE SYSTEM (NW GERMANY): IMPLICATIONS FOR SPELEOTHEM PROXY DATA
}

\author{
Sylvia Riechelmann ${ }^{1, C}$, Sebastian F.M. Breitenbach¹, Andrea Schröder-Ritzrau², Augusto Mangini², \\ and Adrian Immenhauser ${ }^{1}$
}

\begin{abstract}
Cave air $\mathrm{pCO}_{2}$ (carbon dioxide partial pressure) is, along with drip rate, one of the most important factors controlling speleothem carbonate precipitation. As a consequence, $p \mathrm{CO}_{2}$ has an indirect but important control on speleothem proxy data (e.g., elemental concentrations, isotopic values). The $\mathrm{CO}_{2}$ concentration of cave air depends on $\mathrm{CO}_{2}$ source(s) and productivity, $\mathrm{CO}_{2}$ transport through the epikarst and karst zone, and cave air ventilation. To assess ventilation patterns in the Bunker-Emst Cave (BEC) System, we monitored the $p \mathrm{CO}_{2}$ value approximately $100 \mathrm{~m}$ from the lower entrance (Bunker Cave) at bi-hourly resolution between April 2012 and February 2014. The two entrances of the BEC system were artificially opened between 1860-1863 (Emst Cave) and 1926 (Bunker Cave). Near-atmospheric minimum $p \mathrm{CO}_{2}$ dynamics of $408 \mathrm{ppmv}$ are measured in winter, and up to $811 \mathrm{ppmv}$ are recorded in summer. Outside air contributes the highest proportion to cave air $\mathrm{CO}_{2}$, while soil, and possibly also ground air, provide a far smaller proportion throughout the whole year. Cave air $p \mathrm{CO}_{2}$ correlates positively with the temperature difference between surface and cave air during summer and negatively in winter, with no clear pattern for spring and autumn. Dynamic ventilation is driven by temperature and resulting density differences between cave and surface air. In summer, warm atmospheric air is entrained through the upper cave entrance where it cools. With increasing density, the cooled air flows toward the lower entrance. In winter, this pattern is reversed, due to cold, atmospheric air entering the cave via the lower entrance, while relatively warm cave air rises and exits the cave via the upper entrance. The situation is further modulated by preferential south-southwestern winds that point directly on both cave entrances. Thus, cave ventilation is frequently disturbed, especially during periods with higher wind speed. Modern ventilation of the BEC system—induced by artificially openings - is not a direct analogue for pre-1860 ventilation conditions. The artificial change of ventilation resulted in a strong increase of $\delta^{13} \mathrm{C}_{\text {speleothem }}$ values. Prior to the cave opening in 1860 , Holocene $\delta^{13} \mathrm{C}_{\text {speleothem }}$ values were significantly lower, probably related to limited ventilation due to the lack of significant connections between the surface and cave. Reduced ventilation led to significantly higher $\mathrm{pCO}_{2}$ values, minimal $\mathrm{CO}_{2}$ degassing from drip water and low kinetic isotope fractionation. Both modern and fossil speleothem precipitation rates are driven by water supply and carbonate saturation, and not by cave air $p \mathrm{CO}_{2}$. Today, $p \mathrm{CO}_{2}$ variability is too small to affect carbonate precipitation rates and the same is likely true for $\mathrm{pCO}_{2}$ variability prior to artificial opening of the cave. Thus, fossil speleothems from BEC System are likely more sensitive to temperature and infiltration dynamics. The Bunker-Emst Cave System, therefore, represents different ventilation patterns and their influence on speleothem proxy data in an exemplary manner, and it may serve as a template for other cave systems.
\end{abstract}

\section{Introduction}

Over the last two decades, paleoclimate reconstructions based on speleothems increased significantly in number and hind-casting value (Henderson, 2006). Precise ${ }^{230} \mathrm{Th} / \mathrm{U}$ dating and single or multi-proxy geochemical approaches allow for detailed paleoclimate reconstructions (Fairchild and Baker, 2012). A wide range of processes in the soil, epikarst (the uppermost zone of the karst in contact with the soil; Bakalowicz, 2012; Fairchild and Baker, 2012), and karst zone, as well as fractionation dynamics, can alter proxy data. To gain a better and quantitative understanding of the processes involved, sophisticated monitoring programs have been established (Spötl et al., 2005; Mattey et al., 2008, 2010, 2016; Riechelmann et al., 2011, 2017; van Rampelbergh et al., 2014; Breitenbach et al., 2015; Ridley et al., 2015; Czuppon et al., 2018). In this context, a large variety of parameters have been recorded, including surface, soil, and cave air temperature, air pressure, ${ }^{222} \mathrm{Rn}, \mathrm{pCO}_{2}$ (carbon dioxide partial pressure) and humidity, as well as the geochemical composition of rain, soil, and dripwater. Data obtained from such monitoring programs were placed in context with recent carbonate precipitates or speleothems (Miorandi et al., 2010; Tremaine et al., 2011; Riechelmann et al., 2013, 2014; Rossi and Lozano, 2016).

$\mathrm{pCO}_{2}$ values of cave air are generally elevated relative to the outside air (Spötl et al., 2005; Baldini et al., 2006; Riechelmann et al., 2011; Breecker et al., 2012; Mattey et al., 2016). $\mathrm{CO}_{2}$ plays an essential role in speleothem carbonate precipitation (besides the degree of carbonate supersaturation of the dripwater and water supply), as well as on the

${ }^{1}$ Ruhr-University Bochum, Institute of Geology, Mineralogy and Geophysics, Universitätsstraße 150, D-44801 Bochum, Germany

${ }^{2}$ Ruprecht-Karls-University Heidelberg, Institute of Environmental Physics, Im Neuenheimer Feld 229, D-69120 Heidelberg, Germany

cCorresponding author: Sylvia.Riechelmann@rub.de 
fractionation and incorporation of isotopic and elemental signatures in speleothems (Dreybrodt, 1988, 2008; Baldini et al., 2006; Banner et al., 2007; Lechleitner et al., 2016; Pu et al., 2016). Thus, recording cave air $p \mathrm{CO}_{2}$ is critical for those interested in assessing speleothem precipitation behavior and proxy dynamics.

Generally applied concepts imply that rainwater infiltrating the soil zone absorbs plant- and microbial-derived $\mathrm{CO}_{2}$ and constitutes a main source for $\mathrm{CO}_{2}$ in caves. Carbonic acid is produced in the soil and subsoil, dissociates to hydrogen carbonate, and is transported into the cave via fissures in the host rock. Low cave air $p \mathrm{CO}_{2}$ values, relative to the $\mathrm{pCO}_{2}$ of the dripwater, facilitate $\mathrm{CO}_{2}$ degassing, with higher $\mathrm{CO}_{2}$ gradients, leading to higher precipitation rates of calcium carbonate polymorphs (Bögli, 1978; Hammerschmidt et al., 1995; Fairchild and Baker, 2012). A long-underestimated $\mathrm{CO}_{2}$ source is ground air, which exists in gaseous form in the karst vadose zone and is transported into the cave system via fissures, fractures, and pore-space of the rock. More recent studies revealed that ground air is most likely the main source of cave air $\mathrm{CO}_{2}$ rather than soil air (Mattey et al., 2010, 2016; Baldini et al., 2018). $\mathrm{CO}_{2}$ ground air is produced by microbial oxidation of organic matter in infiltrating water, as revealed by radiocarbon measurements, hinting on $\mathrm{CO}_{2}$ derived from the decay of old carbon and elevated $\delta^{13} \mathrm{C}_{\mathrm{CO} 2}$ values (e.g., Atkinson, 1977; Wood, 1985; Noronha et al., 2015; Mattey et al., 2016). Cave lakes or stream water, biological productivity in the cave, and hydrothermal $\mathrm{CO}_{2}$ can act as additional $\mathrm{CO}_{2}$ sources for cave air $\mathrm{CO}_{2}$ (James, 1977; Baldini, 2010; Fairchild and Baker, 2012).

Cave air $\mathrm{pCO}_{2}$ depends on the $\mathrm{CO}_{2}$ productivity of its source, and cave ventilation processes (Fairchild and Baker, 2012; Breitenbach et al., 2015; Lechleitner et al., 2016). Cave ventilation also influences speleothem isotope composition and growth dynamics, hence also trace element incorporation into carbonate. Ventilation can be classified into different types by physical mechanisms: cave breathing, with air pressure differences driving air exchange, wind-induced air flow, chimney circulation driven by air density differences (temperature; at least two cave entrances), convection, either forced or free, due to differences in air density, and water-induced air flow (Fairchild and Baker, 2012). These processes can act from hourly to multi-annual timescales (Fairchild and Baker, 2012). Microclimate monitoring in caves is rarely conducted at excessively high resolution (Tremaine et al., 2011; Breitenbach et al., 2015; Ridley et al., 2015), and, due to logistical limitations, sampling at weekly to monthly intervals still prevails (Spötl et al., 2005; Banner et al., 2007; Riechelmann et al., 2011).

Here, we present results from a two-year-long and bi-hourly resolved monitoring of cave air $p \mathrm{CO}_{2}$, and air temperature in the Bunker-Emst Cave System. Physico-chemical data from modern carbonate precipitates on watch glasses, and speleothem data complement the monitoring dataset. The results are compared with meteorological data to identify the ventilation processes and their physical drivers, document changes in cave air $\mathrm{pCO}_{2}$ at different timescales, and determine the impact of $\mathrm{CO}_{2}$ dynamics on speleothem precipitation and geochemical proxies in the Bunker-Emst Cave System.

\section{Cave Setting and Monitoring Protocol}

The Bunker-Emst Cave (BEC) System is located in the Rhenish Slate Mountains in the NW part of the Sauerland, Germany between the towns of Iserlohn and Letmathe (Fig. 1). This system has two south-oriented entrances. The entrance of Bunker Cave is the lower one of the $3.5 \mathrm{~km}$ long BEC System and is located at 184 meters above sea level ( $\mathrm{m}$ a.s.I.) at $51^{\circ} 22^{\prime} \mathrm{N}$ and $07^{\circ} 40^{\prime} \mathrm{E}$ (Fig. 2A). The Emst Cave entrance is located $197 \mathrm{~m}$ a.s.l. (Fig. $2 \mathrm{~A}$ ), thus is $13 \mathrm{~m}$ higher and was opened from 1860 to 1863, during railway constructions, while Bunker Cave was opened in 1926 during road construction (Grebe, 1993; Hammerschmidt et al., 1995).

Automatic logging of cave $p \mathrm{CO}_{2}$ and cave air temperature was conducted from April 2012 to February 2014 with the monitoring device CORA, equipped with a non-dispersive infrared (NDIR) sensor (Luetscher and Ziegler, 2012). The long-term precision of $p \mathrm{CO}_{2}$ measurements is $\pm 1.6 \%$, with $\pm 3 \%$ accuracy. A bi-hourly measuring interval was chosen to allow detection of diurnal variability. CORA was installed in the Photographer's Chamber (forming part of Chamber 2; Fig. 2), located at a distance of ca. $100 \mathrm{~m}$ from the Bunker Cave (lower) Entrance. Gaps in the record are due to technical problems during the monitoring period.

Two drip-site monitoring setups with watch glasses were placed in Chamber 1 (TS 1 / U I) and Chamber 2 (TS 8 / U IV; Fig. 2). Drip rate and dripwater saturation indices with regard to calcite, as well as carbonate precipitation rates on the watch glasses, and $\delta^{13} \mathrm{C}$ and $\delta^{18} \mathrm{O}$ of precipitated carbonates were measured or calculated. Additionally, soil air was sampled using fixed soil gas lances. Soil air was analyzed for its $\mathrm{CO}_{2}$ concentration and $\delta^{13} \mathrm{C}_{\mathrm{CO} 2}$ value. Details on measurement protocols and analyses can be found in Riechelmann et al. $(2011,2013,2014,2017)$.

Instrumental climate data of the meteorological station Hemer $\left(51^{\circ} 23^{\prime} \mathrm{N}, 07^{\circ} 45^{\prime} \mathrm{E}, 200 \mathrm{~m}\right.$ a.s.l.; www.meteogroup. com; Fig. 1), located $\sim 7 \mathrm{~km}$ northeast of BEC system, are used at hourly resolution (temperature $\left({ }^{\circ} \mathrm{C}\right)$, wind direction $\left({ }^{\circ}\right)$ and wind velocity $\left.\left(\mathrm{km} \mathrm{h}^{-1}\right)\right)$. Calculated standard deviations of mean values of all above mentioned parameters are given as $1 \sigma$. 


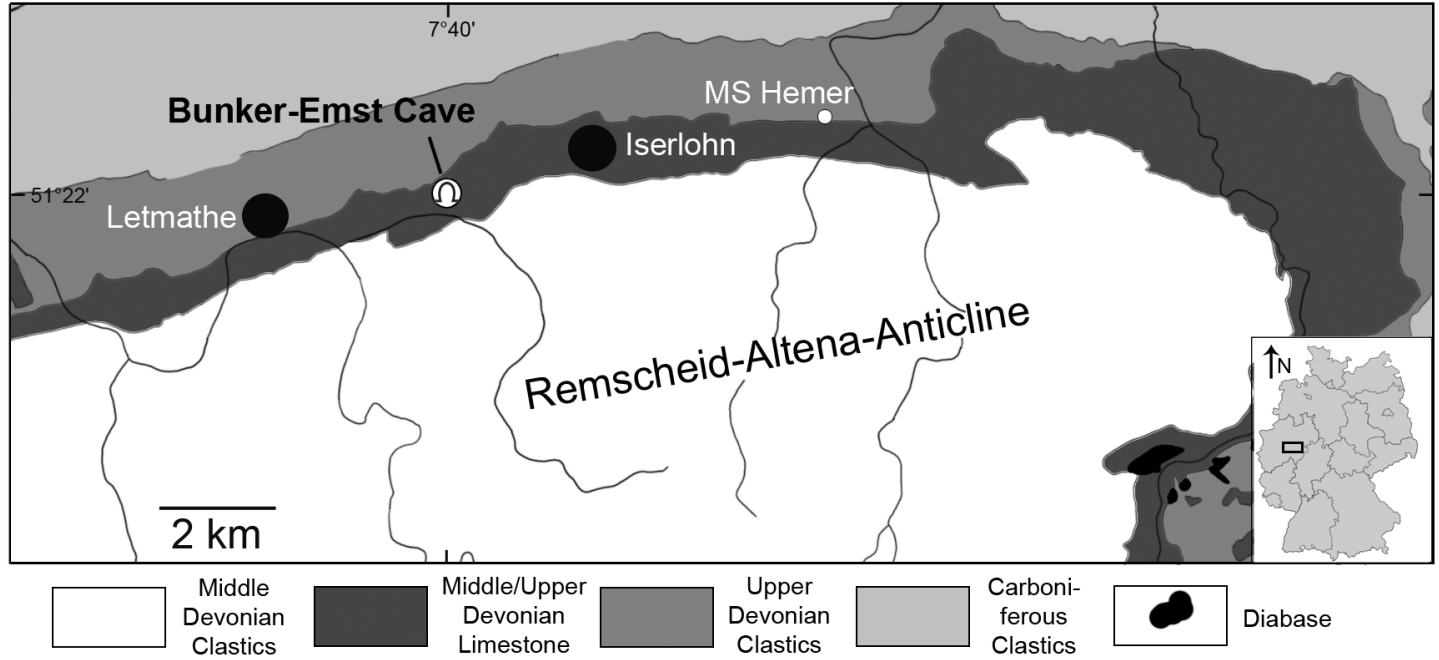

Figure 1. Geological map with the location of Bunker-Emst Cave System and the meteorological station (MS) Hemer.

\section{Results}

\section{Cave Air $\mathrm{pCO}_{2}$ Con- centration}

Bunker-Emst Cave $\mathrm{pCO}_{2}$ values measured with the CORA logger show a longterm mean of $519 \pm$ $84 \mathrm{ppmv} ; n=5248$ ). Seasonal variations display lower $\mathrm{pCO}_{2}$ values in winter (DJF; mean: $490 \pm 29$ ppmv, $n=890)$ and spring (MAM; mean: $454 \pm$ 19 ppmv, $n=1588$ ), and higher values in summer (JJA; mean:
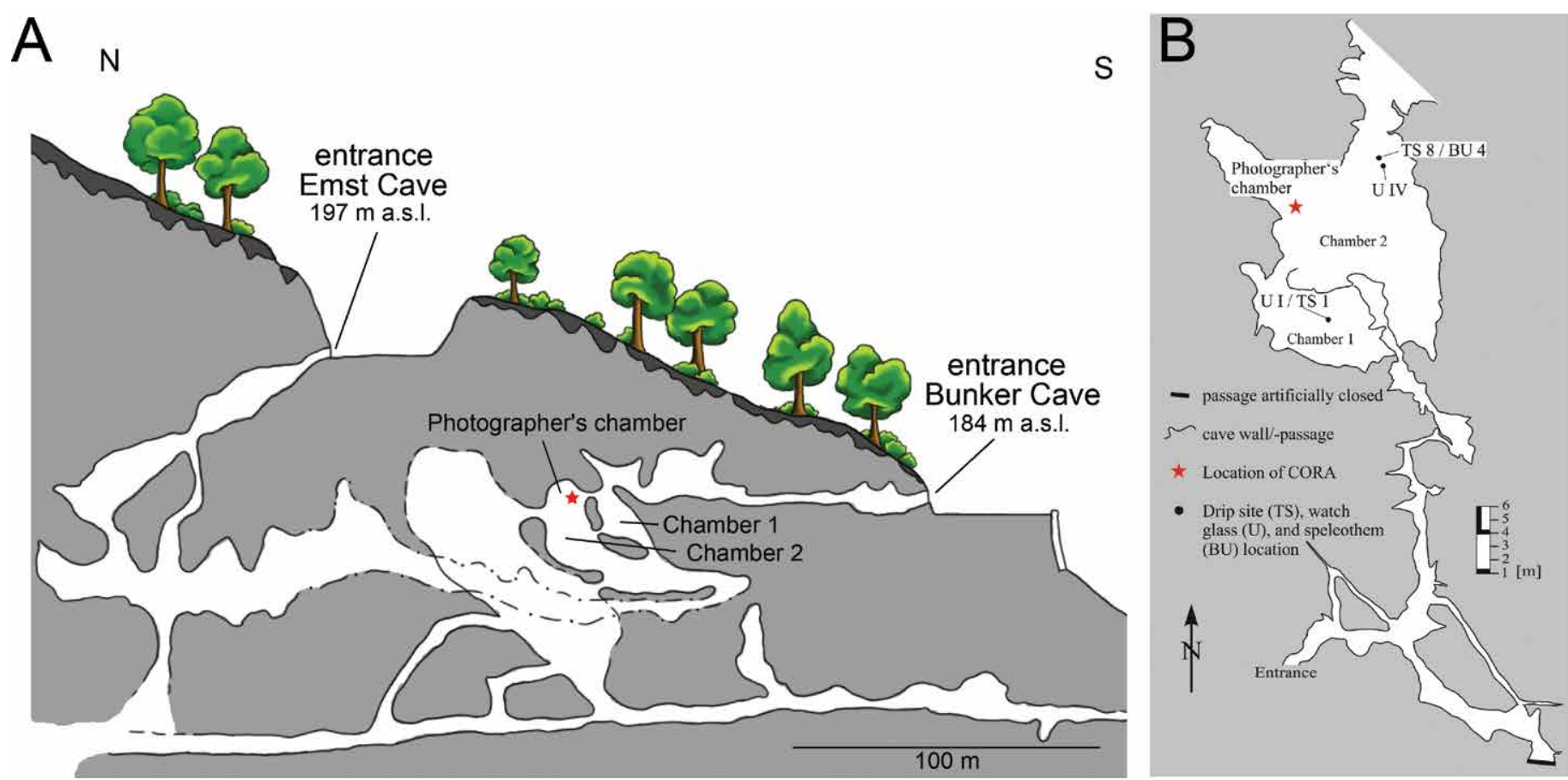

Figure 2. (A) Vertical profile indicating the Photographer's Chamber with the location of the $\mathrm{CO}_{2}$ logger CORA, and the chambers 1 and 2 of previous monitoring (Riechelmann et al., 2011). (B) Map of BEC System with the locations of the $\mathrm{CO}_{2}$ logger $\mathrm{CORA}$ in the Photographer's Chamber and of the drip and watch glass sites TS 1 / U I (Chamber 1) and TS 8 / U IV and speleothem BU 4 in Chamber 2.

$589 \pm 89$ ppmv, $n=1760$ ) and autumn (SON; mean $527 \pm 74$ ppmv, $n=1009)$ months (Fig. 3A). Minimum $p \mathrm{CO}_{2}$ values for all seasons range from 408 to $436 \mathrm{ppmv}$, whereas maximum values are highest in summer (811 ppmv) and autumn (716 ppmv), and lowest in winter (558 ppmv) and spring (598 ppmv). Consequently, the maximal seasonal amplitude of $\mathrm{pCO}_{2}$ values is higher in summer (375 ppmv) and autumn (300 ppmv) than in winter (137 ppmv) and spring (190 ppmv) months.

Monthly $p \mathrm{CO}_{2}$ values vary irregularly from 10 to 160 ppmv over several days up to a few weeks (Fig. 4). Significant $p \mathrm{CO}_{2}$ variations are observed at a diurnal scale, although these patterns are detectable only for a range of a few days, up to a week (Fig. 4). The most obvious examples for strong, diurnal variations were recorded in March and July 2013. In March $2013 p \mathrm{CO}_{2}$ values increased from midnight toward morning, then decreased until the next evening, before they increased again during the next night (Fig. 5A). The opposite behavior is observed in July 2013 (Fig. 5B). A pattern similar to the one observed in March 2013 occurs mostly during the winter months, whereas during summer months, a pattern similar to that in July 2013 is observed. During spring and autumn months, both the winter and the summer patterns can be ob- 
A

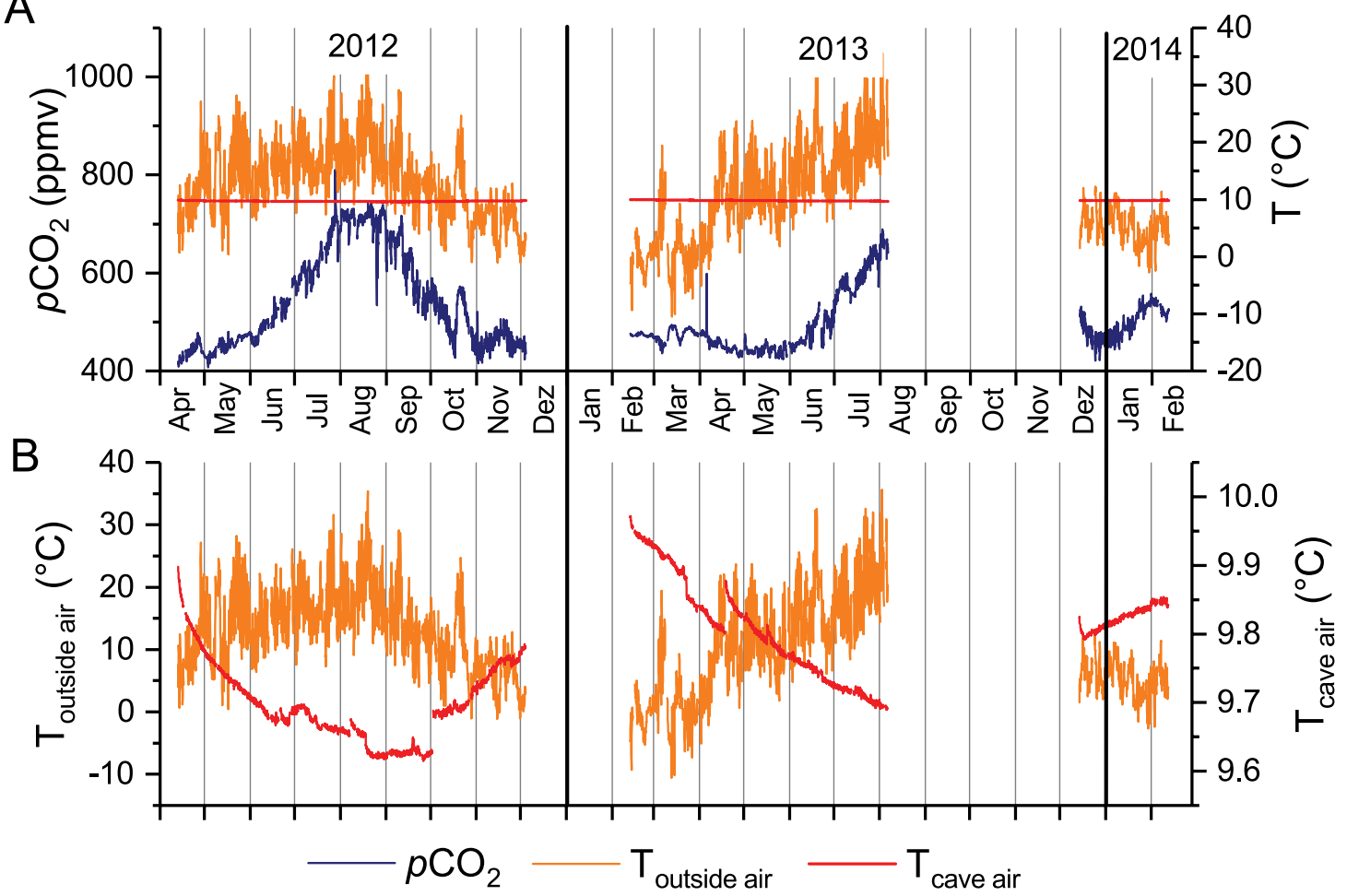

Figure 3. (A) Outside air temperature and cave air $\mathrm{pCO}_{2}$ and temperature at BEC (April 2012 to February 2014). (B) Outside air and cave air temperature. Note the anti-correlation between both curves. served, respectively. Diurnal $\mathrm{pCO}_{2}$ amplitudes reach $10 \mathrm{ppmv}$ to 50 ppmv. Besides the variations described above, significant decreasing $\mathrm{pCO}_{2}$ values with amplitudes of up to 150 ppmv can be observed within a few hours. Such decreasing events were particularly pronounced in August 25, 2012 (150 ppmv) and August 26, 2012 (100 ppmv) (Fig. 6) and July 30-31, 2013 (50 ppmv) (Fig. 4).

Surface and Cave Air Temperatures

The climate of NW Germany is temperate, with no distinct dry season and warm
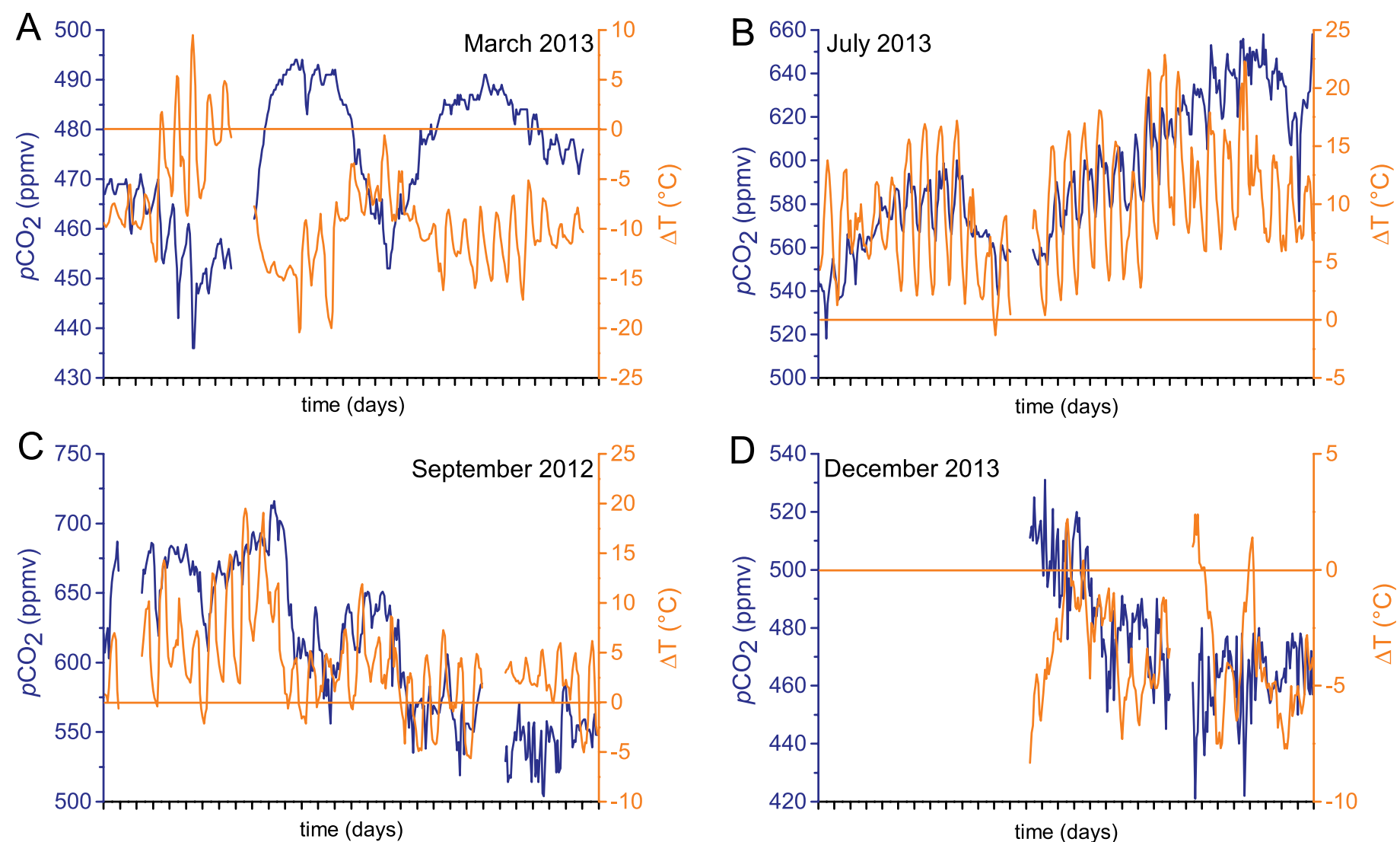

Figure 4. Variations of $p \mathrm{CO}_{2}$ and $\Delta T$ in (A) spring (March 2013), (B) summer (July 2013), (C) autumn (September 2012) and (D) winter (December 2013). Note positive $\Delta T$ values (cave air colder than outside air) in summer and mostly negative ones (cave air warmer than outside air) in winter, while in spring and autumn both positive and negative $\Delta T$ values occur. 
A

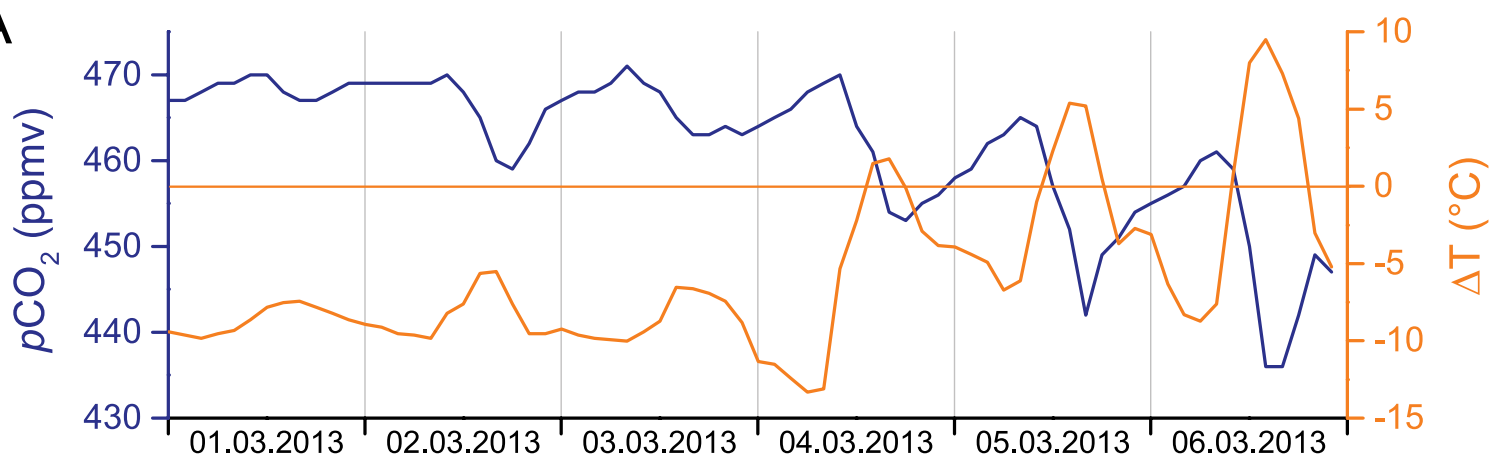

B

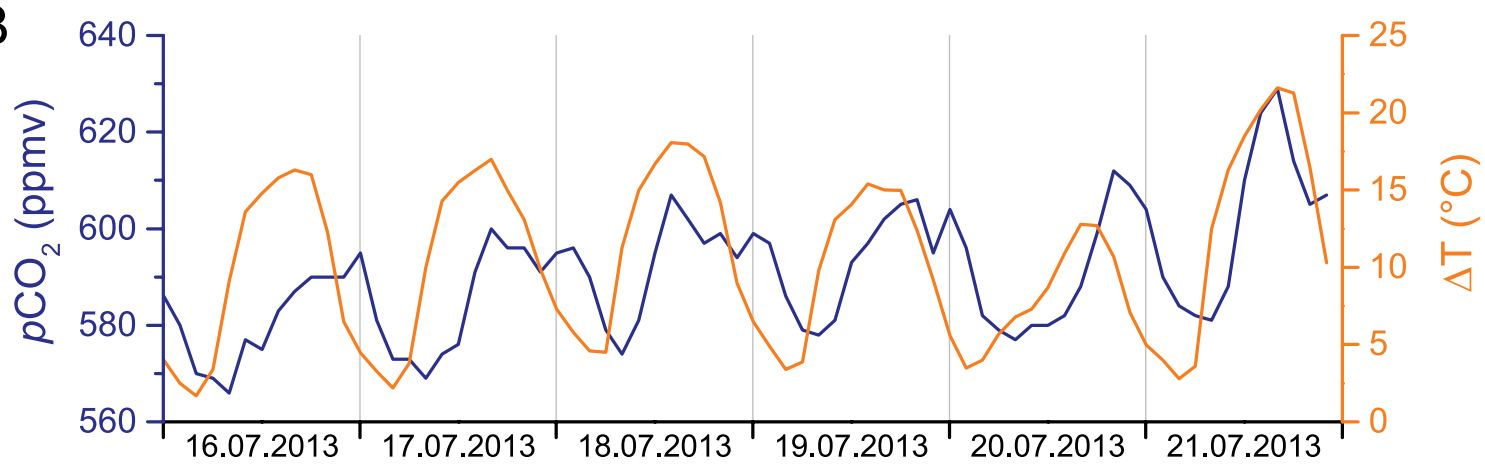

Figure 5. Variations of $p \mathrm{CO}_{2}$ and $\Delta \mathrm{T}$ at diurnal scale in (A) March 2013 and (B) July 2013. Note the anti-correlation between $\mathrm{pCO}_{2}$ and $\Delta \mathrm{T}$ in March and the correlation in July with a small time lag.

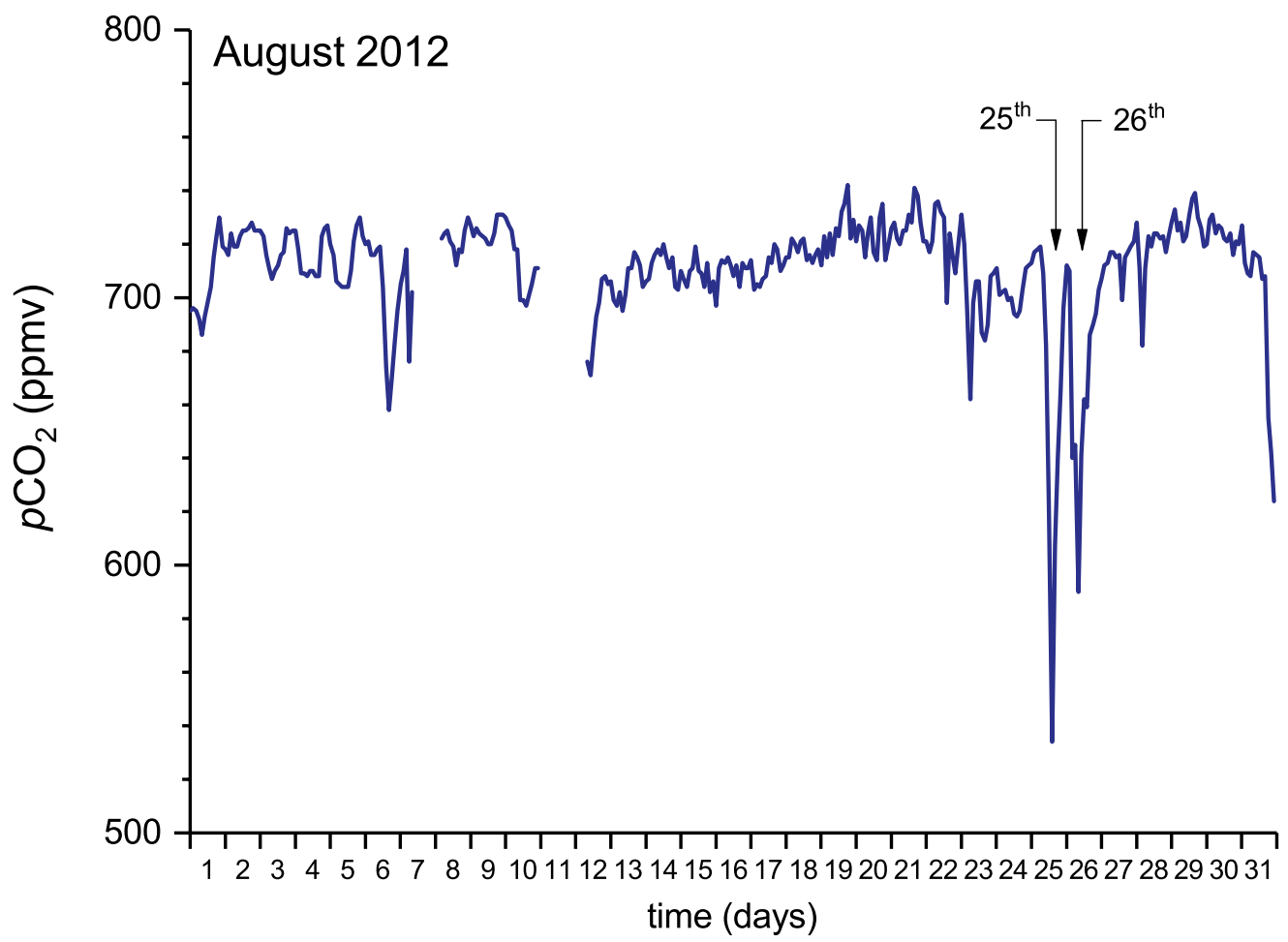

Figure 6. Variations of $p \mathrm{CO}_{2}$ in August 2012. Note the strong decreases in $p \mathrm{CO}_{2}$ during the August 25-26, 2012 period.

ference between $T_{\text {outside air }}$ and $T_{\text {cave air }}$ is:

$$
\Delta T=T_{\text {outside air }}-T_{\text {cave air }}
$$

Negative $\Delta T$ values indicate warmer conditions in the cave, compared to surface conditions, and vice versa. Positive $\Delta T$ values are mainly observed in summer, while $\Delta T$ is usually found to be negative in winter (Fig. 4). In spring and summers. Mean air temperature of the warmest month is below $22{ }^{\circ} \mathrm{C}$, and more than four months have temperatures $>10{ }^{\circ} \mathrm{C}$ (Cfb climate in the Köppen classification, Peel et al., 2007). Over the monitoring period, outside air temperature ranges from $-11.0^{\circ} \mathrm{C}$ (March 2013) to $35.7^{\circ} \mathrm{C}$ (August 2013), with a mean of $10.0 \pm 7.4{ }^{\circ} \mathrm{C}$ $(n=16,771$; Fig. 3). Seasonal variations display lower temperatures in winter (DJF; mean: $3.4 \pm$ $4.1{ }^{\circ} \mathrm{C}, n=4320$ ) and higher temperatures in summer (JJA; mean: $17.4 \pm 5.2{ }^{\circ} \mathrm{C}, n$ $=4416$ ). Spring (MAM; mean: $\left.8.9 \pm 6.9^{\circ} \mathrm{C}, n=3672\right)$ and autumn (SON; mean: $10.0 \pm$ $5.3^{\circ} \mathrm{C}, n=4363$ ) months display temperatures close to the yearly mean.

Cave air temperature ( $T_{\text {cave }}$ air) is rather constant compared to outside air temperature $\left(T_{\text {outside air }}\right)$ with a mean of $9.8 \pm 0.1^{\circ} \mathrm{C}(n=5248)$ (Fig. $3 \mathrm{~A})$. The difference between maximum $\left(10.0{ }^{\circ} \mathrm{C}\right.$; February 2013) and minimum $T_{\text {cave air }}$ $\left(9.6{ }^{\circ} \mathrm{C}\right.$; August and September 2012) recorded values of $0.4{ }^{\circ} \mathrm{C}$ (Fig. 3B). Lowest $T_{\text {cave }}$ air values are observed in summer and autumn, while the highest values occur in winter and spring (Fig. 3B). The dif- 
autumn, $\Delta T$ switches between positive and negative values over weeks and even within a day (Figs. 4 and 5). Diurnal $\Delta T$ changes are also observed for all seasons, with decreasing values at night and increasing ones during daytime (Figs. 4 and 5). Although this pattern is mostly well pronounced (e.g., July 2013, Fig. 4), irregular patterns may occur. An example of an irregular pattern was recorded in December 2013 (Fig. 4).

\section{Wind Directions and Velocity}

Winds above the cave are characterized by preferential southerly to westerly directions (Fig. 7B-C). The mean wind direction from April 2012 to February 2014 is $193^{\circ} \pm 83^{\circ}$ (i.e., SSW; $n=16,769$ ). Mean wind directions vary between southerly directions in winter and spring, and SSW directions in summer and autumn. Only during February and March 2013, the wind blew mainly from northern to eastern directions (Fig. 7A). The mean wind velocity was $9.2 \pm 5.1 \mathrm{~km} \mathrm{~h}^{-1}$ $(n=16,769)$, with a maximum of $35.2 \mathrm{~km} \mathrm{~h}^{-1}$ (December 2013). Wind velocities are lower during summer (JJA; mean $7.7 \pm 4.0 \mathrm{~km} \mathrm{~h}^{-1}, n=4416$ ) and higher in winter (DJF; mean: $11.4 \pm 6.0 \mathrm{~km} \mathrm{~h}^{-1}, n=4320$; Fig. 7). Spring and autumn months display intermediate, mean wind speeds (MAM: $9.2 \pm 4.8 \mathrm{~km} \mathrm{~h}^{-1}, \mathrm{n}=3672$; SON: $8.4 \pm 4.8 \mathrm{~km} \mathrm{~h}^{-1}, n=4361$; Fig. 7).

\section{Dripwater and Carbonate Precipitates}

Drip sites TS 1 / U I and TS 8 / U IV have been monitored (from 2006 to 2013) to evaluate carbonate precipitation rate dynamics. Here, data from 2012 to 2013, i.e., the same time interval as the $\mathrm{pCO}_{2}$ monitoring, is presented. Drip rates, $S I_{\mathrm{CC}}$ and carbonate precipitation rates are higher for site TS 1 / U I compared to site TS 8 / U IV (Fig. 8). At both watch glass sites, precipitation rates are higher during winter and spring and lower during summer and autumn (Fig. 8). At TS 1, water supply (drip rate) is highest in spring, whereas drip rates are rather constant at site TS 8 . At site TS 1, the $S I_{\mathrm{CC}}$ displays an increasing trend over the monitoring period, while at site TS $8 \mathrm{SI}_{\mathrm{CC}}$ shows highest values in spring and summer (Fig. 8). Carbonates precipitated at site TS $1 / \mathrm{U}$ I display lower $\delta^{18} \mathrm{O}$ and $\delta^{13} \mathrm{C}$ values in contrast to precipitates at site TS 8 / U IV (Fig. 9A). Generally, $\delta^{18} \mathrm{O}$ and $\delta^{13} \mathrm{C}$ values of carbonate precipitates on watch glasses are higher in winter and spring, but the variability of data is relatively small (Fig. 9A).

\section{Interpretation and Discussion}

\section{Heat Transport Mechanism}

\section{The Bun- ker-Emst Cave} air temperature is close to the mean annual outside air temperature and the seasonal cave air temperature pattern is close to a sinusoidal curve (Fig. 3). This implies that heat conduction is the main factor influencing cave air temperature. Thereby, the outside air temperature is recorded by the soil and transmitted to the host rock (e.g., Pollack and Huang, 2000; Smerdon et al., 2006). The transport mechanism of heat conduction through the host rock depends on its thermal
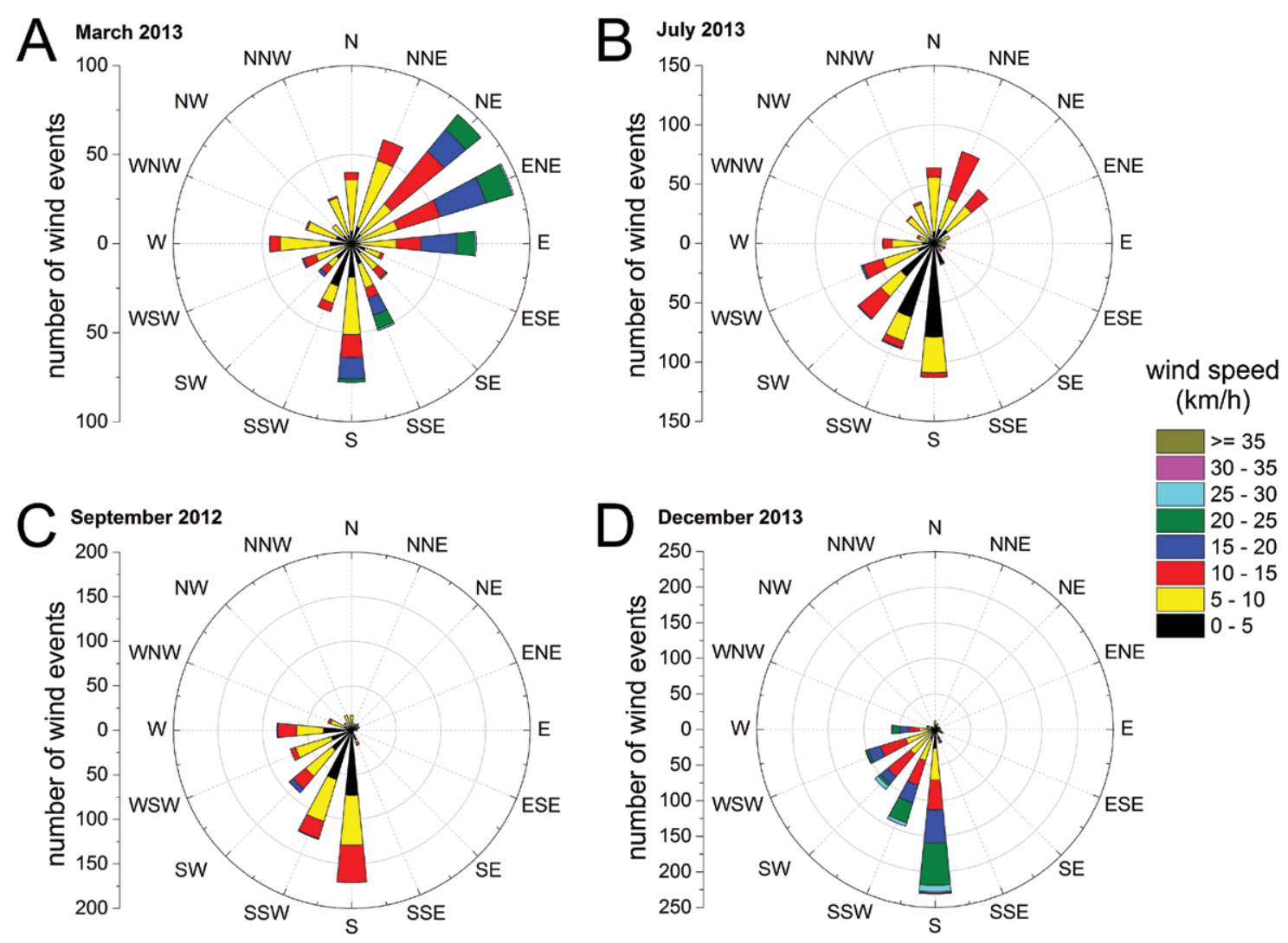

Figure 7. Wind directions, number of wind events and respective wind speed in (A) spring (March 2013), (B) summer (July 2013), (C) autumn (September 2012) and (D) winter (December 2013). Higher wind speeds occur mostly in winter months and occasionally in spring and autumn. Southern to western directions are the preferred wind directions. 


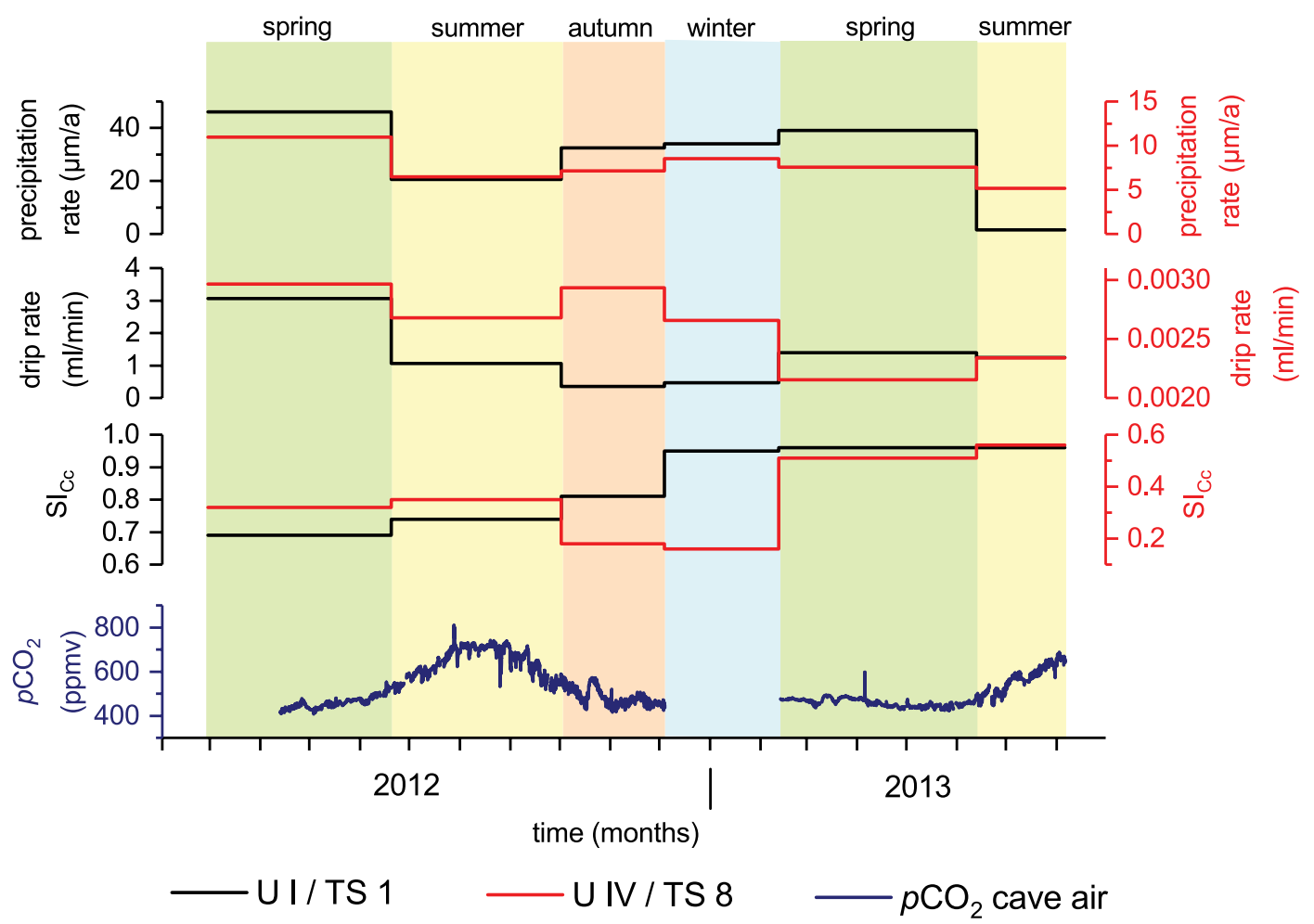

Figure 8. Carbonate precipitation, drip rate and saturation index of calcite of recent watch- glass precipitates (U I and U IV) and their respective drip waters (sites TS 1 and TS 8) as well as cave air $p \mathrm{CO}_{2}$. diffusivity, resulting in a time lag between outside air and cave air temperature. Inverse temperature curves of outside and cave air (Fig. 3B) suggest a time lag of approximately six months. Nevertheless, such short time lags are only observed for very shallow portions of the cave $(<5 \mathrm{~m}$ in depth; Domínguez-Villar, 2012), whereas the rock overburden of the photographer's chamber, the main study site documented in this paper, is on the order of 15 to 30 m (Grebe, 1993). Under these conditions, a time lag of several years is expected. Heat advection induced by ventilation adds additional noise to the cave air temperature record, resulting in an asymmetrical curve (Domínguez-Villars, 2012). In BEC, this is best observed between June to September 2012 (Fig. 3B). The total contribution of heat advection is, however, small due to the relatively small entrances. Therefore, the authors conclude that $T_{\text {cave air }}$ is mainly influenced by heat transferred by conduction, and on a smaller scale by heat advection due to ventilation.

\section{Cave Air $\mathrm{CO}_{2}$ Sources}

Compared to other caves worldwide, the BEC System displays relatively low cave air $p \mathrm{CO}_{2}$ values (Spötl et al., 2005; Baldini et al., 2006; Banner et al., 2007; Cowan et al., 2013; Pla et al., 2016; Pu et al., 2016). Previous $\mathrm{CO}_{2}$ mea-

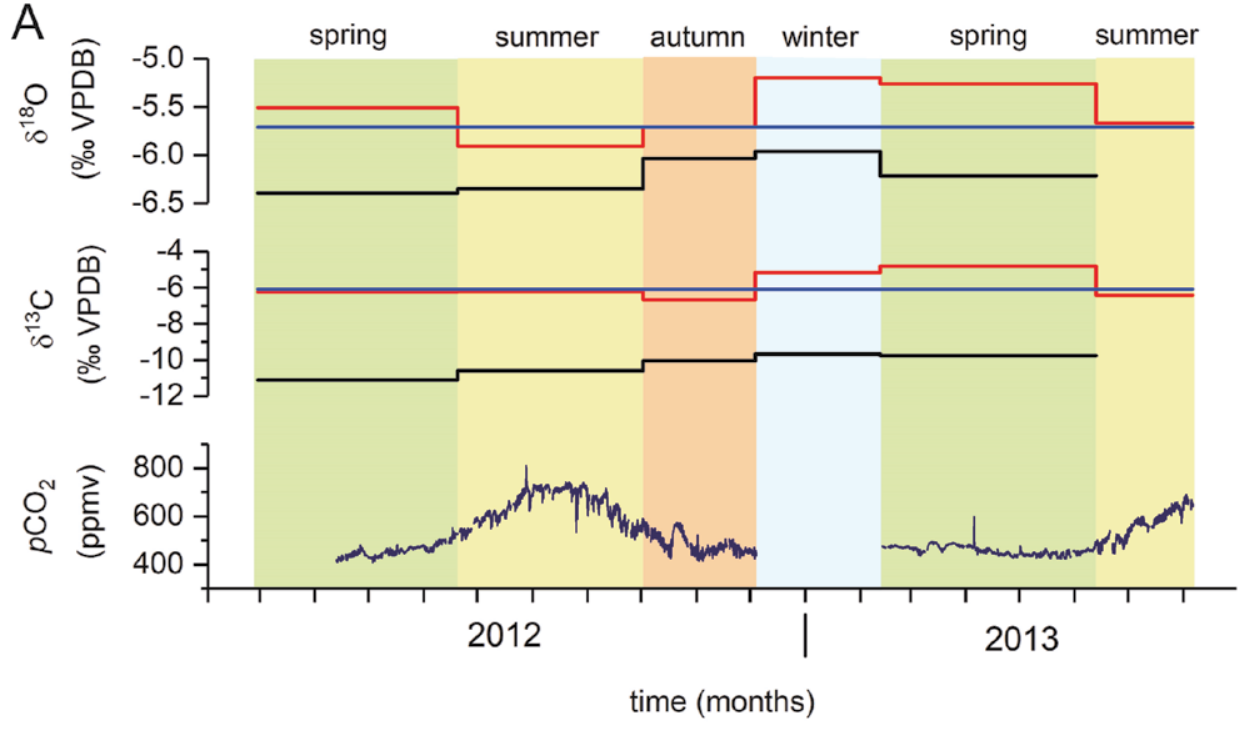

$-\mathrm{UI} / \mathrm{TS} 1-\mathrm{U}$ IV / TS $8-\mathrm{BU} 4-\mathrm{CO}_{2}$ cave air

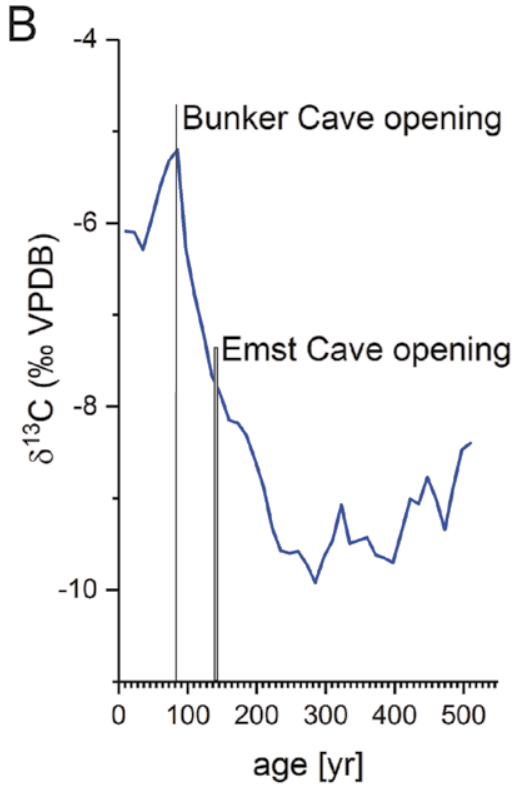

Figure 9. (A) Oxygen and carbon isotope values of modern watch-glass precipitates (U I and U IV) and of the most recent part of speleothem $\mathrm{BU} 4$, as well as cave air $\mathrm{pCO}_{2}$. Note that oxygen and carbon isotopic composition of BU 4 corresponds to that of watch glass $\mathrm{U}$ IV. (B) Carbon isotope signatures of the last 500 years of speleothem BU 4. The opening of both cave entrances is marked. Data are from Fohlmeister et al. (2012). 
surements in Chamber 1, Chamber 2, and the Photographer's Chamber in Bunker Cave (Fig. 2) revealed $\mathrm{CO}_{2}$ concentrations between 580 to 1200 ppmv (Riechelmann et al., 2011). These are higher than those measured in the current study. This discrepancy is assumed to be a methodological artifact, since Riechelmann et al. (2011) measured with a hand-held device during the monthly monitoring tours, and contamination of cave air with human breath could not be fully excluded in the narrow cave chambers. Consequently, we assume the $\mathrm{CO}_{2}$ data of the current study to be more representative of the $\mathrm{CO}_{2}$ variability in the $\mathrm{BEC}$ System than the previous measurements. $p \mathrm{CO}_{2}$ values in winter and spring (minimum 408 ppmv) in BEC System are only slightly higher than outside air values, while summer and autumn in-cave $\mathrm{pCO}_{2}$ values are slightly elevated (up to 811 ppmv; Fig. 3A). Hence, the relatively low $p \mathrm{CO}_{2}$ values observed throughout the year in the BEC System suggest a continuous exchange between cave and outside air $(\sim 398 \mathrm{ppmv}$ (2012-2014); air monitoring station Schauinsland, Germany; German Federal Environmental Agency, 2018). Nevertheless, an independent source introducing $\mathrm{CO}_{2}$ to the cave air is required to explain the higher summer and autumn $\mathrm{pCO}_{2}$ values. There is no evidence for $\mathrm{CO}_{2}$ degassing from cave lakes or streams and hydrothermal $\mathrm{CO}_{2}$ in the $\mathrm{BEC}$ System (Riechelmann et al., 2011). $\mathrm{CO}_{2}$ produced by microbial activity, however, in the cave was not assessed, so this might represent a possible, but poorly quantified, source of $\mathrm{CO}_{2}$. The most likely sources of $\mathrm{CO}_{2}$ in the BEC System and its seasonal variability, however, are increased soil zone activity in summer, driven by higher temperatures and soil humidity (e.g., Tremaine et al., 2011; Ek and Godissart, 2014), or seasonal, varying ground air produced by microbial activity in the vadose karst zone being introduced into the cave system (Mattey et al., 2010, 2016; Baldini et al., 2018).

Previous work, taking measurements of the $\delta^{13} \mathrm{C}_{\mathrm{CO} 2}$ of soil air above BEC System, suggested a mean value of -22 $\% o$ (Riechelmann et al., 2011). This relatively high value might be due to a methodological offset. The portable soil gas probe, used by Riechelmann et al. (2011) for sampling, might have contaminated the sample with surface air (with a mean value of $\sim-8 \%$ ). Sampling with a fixed soil gas lance gave $\delta^{13} \mathrm{C}_{\mathrm{CO} 2}$ values of up to $-28 \%$ for soil air, suggesting C3 plants as a source for soil air $\mathrm{CO}_{2}$. The $\delta^{13} \mathrm{C}$ values of $\mathrm{C} 3$ plant respiration varies between $-22 \%$ to $-35 \%$ with a mean value of -27 \% (e.g., Bender, 1971; O'Leary, 1988; Madhavan et al., 1991; Glaser, 2005). Soil zone $\mathrm{CO}_{2}$ is delivered to the cave system via dripwater, and additionally through open cracks and fissures in the host rock (Baldini et al., 2006). Ground air is another alternative source for cave air $p \mathrm{CO}_{2}$. Being mainly produced in the vadose zone of karst aquifers, gaseous ground air $\mathrm{CO}_{2}$ is transported via fissures, fractures, and pore-space of the rock (e.g., Atkinson, 1977). Modelled and measured $\delta^{13} \mathrm{C}_{\mathrm{CO} 2}$ rates of gaseous ground air (in boreholes) suggest values between $-24 \%$ and $-18 \%$ (Benavente et al., 2010; Mattey et al., 2016). In the BEC system, cave air $p \mathrm{CO}_{2} \delta^{13} \mathrm{C}$ values vary between $-14 \%$ and $-17 \%$. On the basis of the $\delta^{13} C_{\text {CO2 }}$ values, it cannot be established which is the lower endmember source (ground air or soil air $\mathrm{CO}_{2}$ ). In previous work, Riechelmann et al. (2011) suggested that Bunker Cave air represents an admixture between soil air and outside air. Baldini et al. (2018), in contrast, suggested ground air as an additional source for cave air in several cave sites worldwide (including Bunker Cave). Because ground air $\mathrm{CO}_{2}$ concentrations are often very high, and range between 12,000 to 70,000 ppmv (occasionally even higher than soil air $\mathrm{CO}_{2}$ concentrations; e.g., Atkinson, 1977; Benavente et al., 2010; Hendry and Wassenaar, 2005; Baldini et al., 2018), the contribution of ground air to cave air $p \mathrm{CO}_{2}$ is expected to be small, in view of the low cave air $\mathrm{CO}_{2}$ concentrations. Soil air $\mathrm{CO}_{2}$ concentrations reach up to 11,000 ppmv above the BEC System (Riechelmann et al., 2011); thus, the contribution of soil air to cave air can also be expected to be small.

Mattey et al. (2016), reported large seasonal $\mathrm{CO}_{2}$ variations in boreholes. Exceptions included only the deepest portions of these boreholes, where no difference between summer and winter month values was found. Consequently, seasonal variation of cave air $p \mathrm{CO}_{2}$ can be explained by seasonal variations in soil air or ground air. Because ground air is so much more enriched in $\mathrm{CO}_{2}$ compared to soil air, and cave air displays such low concentrations, we argue that the fraction of soil air contributing to cave air is higher than the fraction of ground air. Although, both have to be low compared to the fraction of outside air. By applying a simple mass balance, the fractions of outside air and soil air (ground air) can be estimated. The following equation is used here:

$$
F_{\text {outside air }} \times \mathrm{CO}_{2 \text { outside air }}+F_{\text {soil air }} \times \mathrm{CO}_{2 \text { soil air }}=1 \times \mathrm{CO}_{2 \text { cave air }}
$$

where

$$
\begin{gathered}
F_{\text {soil air }}=1-F_{\text {outside air }} \\
F_{\text {outside air }}=\frac{\left(\mathrm{CO}_{2} \text { cave air }-\mathrm{CO}_{2 \text { soil air }}\right)}{\left(\mathrm{CO}_{2} \text { utside air }-\mathrm{CO}_{2} \text { soil air }\right)}
\end{gathered}
$$

where $F_{\text {outside air }}$ is the fraction of the outside air, $F_{\text {soil air }}$ is the fraction of soil air, and $\mathrm{CO}_{2}$ refers to the $\mathrm{CO}_{2}$ concentrations of each air type. Calculations were made for winter (DJF) and summer (JJA), using the mean $\mathrm{CO}_{2}$ cave air values of these months as described above. The $\mathrm{CO}_{2}$ concentration of outside air is assumed to be 398 ppmv (2012-2014; air 
monitoring station Schauinsland, Germany; German Federal Environmental Agency, 2018), whereas soil air $\mathrm{CO}_{2} \mathrm{con}_{-}$ centration is 1170 ppmv in winter and 6600 ppmv in summer. This results in a mixing of $88 \%$ outside air and $12 \%$ soil air (or ground air) in winter and $97 \%$ outside air and 3\% soil air (or ground air) in summer. When inserting the minimum $p \mathrm{CO}_{2}$ value in winter (408 ppmv) and the maximum $\mathrm{pCO}_{2}$ value in summer (811 ppmv) in the above equations, a fraction of $99 \%$ outside air in winter and $93 \%$ outside air in summer results. We conclude that the main contribution to cave air is outside air, while soil and ground air represent a far smaller proportion. Hence, the ventilation in BEC System is generally well developed.

\section{Ventilation Systematics in Bunker-Emst Cave System}

Due to its two entrances, the BEC System exhibits a dynamic ventilation sensu Geiger (1961), and with the entrances being on different levels (13 $\mathrm{m}$ vertical difference), chimney circulation is suggested as the possible ventilation mechanism. This is supported by the observed airflow directions in the narrow passage connecting the Bunker Cave Entrance with Chamber 1 (Fig. 2), as measured during the monitoring tours. During summer months, the preferential direction was an outflow through the lower entrance, whereas during winter months, we observed inflow of air through the lower entrance. Particularly during very cold days $\left(-10^{\circ} \mathrm{C}\right.$ to $\left.0{ }^{\circ} \mathrm{C}\right)$, ascending warm, humid air could be detected at the upper Emst Cave Entrance. Since the logging device is close to the lower entrance and on a similar altitude with it, the ventilation concept applies only for passages and chambers near the two entrances, where cave and outside air interact and coalesce (Tremaine et al., 2011; McDonough et al., 2016). We would like to emphasize that the $p \mathrm{CO}_{2}$ levels and ventilation systematics of deeper parts of the BEC System remain poorly constrained at present, since no monitoring of these portions of the cave has been performed. We assume, however, that the deeper parts of the cave have higher $\mathrm{CO}_{2}$ concentrations because of significantly reduced ventilation in these passages. In contrast, increasing amounts of ground air are observed in other cave systems (Baldini et al., 2006, 2018; Mattey et al., 2016).

Chimney circulation is driven by air density gradients between outside and cave air. These, in turn, are governed by air temperature differences (Fairchild and Baker, 2012). Another possible driving factor is a pressure difference induced by the altitude gradient of the cave entrances. This scenario, however, seems unlikely because the altitude difference is too small, and pressure differences above the cave (on level with Emst Cave Entrance) relative to such taken inside the cave revealed no difference. As outlined above, positive $\Delta T$ values imply warm outside air and cold cave air, which is the usual pattern during summer months. Conversely, during winter, the cave is warmer than the land surface and $\Delta T$ values are negative (Fig. 3). Monthly (and diurnal) $\Delta T$ values and cave air $p \mathrm{CO}_{2}$ are mostly positively correlated in summer, and negatively in winter, whereas autumn and spring months show both positive and negative correlations (Table 1). We conclude that $p \mathrm{CO}_{2}$ variations are driven by temperature (density) differences.

Generally, two different ventilation regimes can be discerned: a summer (positive $\Delta T$ values and positive correlation) and a winter (negative $\Delta T$ values and negative correlation) pattern. During summer (Fig. 4 and Table 1), warm surface air enters the upper entrance. The air cools down while passing through the cave, and hence, its density increases, resulting in outflowing colder air through the lower entrance (Fig. 10A). During winter months, this pattern is reversed; cold and dense surface air enters through the lower entrance. After warming in the cave, this air mass ascends toward the upper entrance, where it leaves the cave (Fig. 10B). In spring and autumn, ventilation switches back and forth, depending on $\Delta T$, at monthly to daily timescales. During these transitional periods, surface temperatures can be warmer than cave air temperatures during day, but colder during the night. Furthermore, ventilation can stagnate if $\Delta T$ values are close or equal to zero, reflected in lacking correlation between $p \mathrm{CO}_{2}$ and $\Delta T$ (Table 1). However, increasingly negative or positive $\Delta T$ values result in higher variations of $\mathrm{pCO}_{2}$ due to intensified ventilation. Similar ventilation patterns were also observed in other cave systems (e.g., De Freitas et al., 1982; Spötl et al., 2005; Tremaine et al., 2011; Gregorič et al., 2014).

Changes in $\Delta T$ are due to outside air temperature being influenced by insolation, cloudiness, wind speed, and occurrences of warm or cold fronts (Lauer and Bendix, 2006). Consequently, $\Delta T$ and $p \mathrm{CO}_{2}$ do not only display clear diurnal signals, such as in March and July 2013, but also irregular patterns, depending on surface weather conditions (Figs. 4 and 5). Both March and July 2013, displayed stable and rather extreme weather conditions over longer time periods, leading to well-defined diurnal patterns driven solely by insolation. During March 2013, extremely cold, arctic air reached NW Germany, leading to preferential wind from northern to eastern directions and generally too cold temperatures for March (Fig. 7A; DWD, 2013a), whereas in July, a stable, high-pressure cell developed resulting in warm temperatures (DWD, 2013b).

Diurnal $p \mathrm{CO}_{2}$ variations in winter and summer are governed by more complex processes. Surface temperature usually increases with insolation during the day, and thus, $\Delta T$ increases too, while at night, the surface cools and $\Delta T$ decreases (Figs. 4 and 5). During winter months, however, we observe that daily $\mathrm{pCO}_{2}$ anti-correlates with $\Delta T$. A possible explanation is suction of $\mathrm{CO}_{2}$ from ground air or soil air into the cave through host rock fissures, or from deeper cave parts during the night hours when ventilation is intensified (Fig. 5A). This is because both soil and deeper cave air 
Table 1. Correlation values between monthly $\mathrm{pCO}_{2}$ and $\Delta \mathrm{T}$.

\begin{tabular}{cccc}
\hline $\mathbf{C O}_{\mathbf{2}}$ vs. $\boldsymbol{\Delta} \mathbf{T}$ & $\boldsymbol{r}$ & $\boldsymbol{p}$ & $\boldsymbol{n}$ \\
\hline Apr 12 & $\mathbf{0 . 3 2}$ & $\mathbf{3 . 6 0 \times 1 0 ^ { - 6 }}$ & $\mathbf{1 9 8}$ \\
May 12 & $\mathbf{0 . 3 0}$ & $\mathbf{4 . 4 6 \times \mathbf { 1 0 } ^ { - 9 }}$ & $\mathbf{3 5 5}$ \\
Jun 12 & $\mathbf{0 . 5 4}$ & $\mathbf{0}$ & $\mathbf{3 1 3}$ \\
Jul 12 & $\mathbf{0 . 2 4}$ & $\mathbf{4 . 3 6 \times \mathbf { 1 0 } ^ { - 6 }}$ & $\mathbf{3 5 6}$ \\
Aug 12 & $\mathbf{0 . 1 6}$ & $\mathbf{0 . 0 0 2}$ & $\mathbf{3 4 7}$ \\
Sep 12 & $\mathbf{0 . 5 2}$ & $\mathbf{0}$ & $\mathbf{3 2 8}$ \\
Oct 12 & $\mathbf{0 . 5 4}$ & $\mathbf{0}$ & $\mathbf{3 3 7}$ \\
Nov 12 & 0.00 & 0.93 & 344 \\
Dec 12 & -0.03 & 0.83 & 42 \\
Feb 13 & -0.06 & 0.47 & 174 \\
Mar 13 & $\mathbf{- 0 . 8 0}$ & $\mathbf{0}$ & $\mathbf{3 4 5}$ \\
Apr 13 & $\mathbf{- 0 . 4 4}$ & $\mathbf{0}$ & $\mathbf{3 3 8}$ \\
May 13 & $\mathbf{0 . 3 5}$ & $\mathbf{9 . 6 6 \times 1 0 ^ { - 1 2 }}$ & $\mathbf{3 5 1}$ \\
Jun 13 & $\mathbf{0 . 1 9}$ & $\mathbf{4 . 1 7} \times \mathbf{1 0}$ & $\mathbf{3 4 0}$ \\
Jul 13 & $\mathbf{0 . 4 3}$ & $\mathbf{0}$ & $\mathbf{3 5 6}$ \\
Aug 13 & $\mathbf{0 . 6 0}$ & $\mathbf{4 . 4 7 \times 1 0 ^ { - 6 }}$ & $\mathbf{4 9}$ \\
Dec 13 & -0.06 & 0.42 & 197 \\
Jan 14 & $\mathbf{- 0 . 7 0}$ & $\mathbf{0}$ & $\mathbf{3 5 6}$ \\
Feb 14 & -0.17 & 0.06 & 122 \\
\hline Negtve & &
\end{tabular}

Note: Negative correlations occurred most often in winter and positive correlations occurred most often in summer, while spring and autumn show both, positive and negative correlations. Significant correlations are printed bold. are enriched in $\mathrm{CO}_{2}$. Although in winter, soil air is less concentrated in $\mathrm{CO}_{2}$ due to lower plant activity. When $\Delta T$ returns to less negative values (near zero) during the day, ventilation diminishes, and this suction effect is weaker or absent. Thus, $\mathrm{pCO}_{2}$ decreases due to higher inflow of outside air from the lower entrance. In summer, daily $p \mathrm{CO}_{2}$ and $\Delta T$ values correlate positively. Due to more positive $\Delta T$ values during the day, ventilation is increased. A suction of soil air or ground air $\mathrm{CO}_{2}$ through fissures in the host rock, or from deeper cave portions, leads to increased $p \mathrm{CO}_{2}$ values. During summer months, air enters through the upper entrance and flows out through the lower entrance. Hence, it seems possible that ground air from deeper parts of the cave system is sucked into the main airflow path between the two entrances, leading to a higher fraction of ground air contributing to cave air. During night hours, ventilation intensity decreases ( $\Delta T$ values are less positive) and, consequently, $p \mathrm{CO}_{2}$ decreases, too. The $\mathrm{CO}_{2}$ variability of outside air at BEC System was not recorded in the context of this study. However, it can be assumed that outside air $\mathrm{CO}_{2}$ variability, although small (Keeling et al., 2005), influences $\mathrm{pCO}_{2}$ cave air variability at diurnal and seasonal scale.

Obviously, $p \mathrm{CO}_{2}$ slightly lags variations in $\Delta T$ (Fig. 5). This is best explained by the intensity and rapidity of adjustment of the ventilation, and the distance the air needs to pass from the entrance to reach the data logger. We computed running correlations for the periods with the most pronounced diurnal variations (March 2013 and July 2013; Fig. 5) to determine the lag between change of outside temperature (air density) and response of $\mathrm{pCO}_{2}$ levels in the cave. The running correlations suggest a lag of two hours for March 2013, and six hours for July 2013. Since the $\mathrm{CO}_{2}$ logger is at a distance of only $100 \mathrm{~m}$ to the lower entrance, the shorter transfer time in March 2013 is easily explained. Surface air entering the lower entrance in winter reached the logger three times faster compared to summer months, when the air enters through the upper entrance and has to overcome a distance of $\sim 300 \mathrm{~m}$ to reach the logger. This results, in both cases, in an especially low air flow velocity of $0.014 \mathrm{~m} \mathrm{~s}^{-1}$. Due to this, air entering the cave through the lower or upper entrance is near-equilibrated with rock temperature when it reaches the logger. This is documented by the low, cave air temperature variability due to heat advection (Fig. 3B). Air flow velocity, however, is expected to vary throughout the year.

Most variations of cave air $\mathrm{pCO}_{2}$ can be explained by temperature-driven air density differences. An additional factor, however, influences the ventilation pattern and is responsible for strong $\mathrm{CO}_{2}$ decreases of up to $150 \mathrm{ppm}$ within a few hours (Figs. 4 and 6). This secondary ventilation pattern for the BEC System is wind-induced flow. Wind-induced flow is facilitated by the orientation of both cave entrances toward the south, and thus, toward the main wind sector (Figs. 4, 6 and 7). Particularly, during periods of higher wind speed, and especially during winter months, the normal chimney circulation is disturbed; surface air is blown into the cave, lowering the $\mathrm{CO}_{2}$ level. The period of August 25-26, 2012 was particularly well suited to exemplify this wind-induced disturbance. August 25, 2012 wind speed varied between 13 to $19 \mathrm{~km} \mathrm{~h}^{-1}$, with directions between $190^{\circ}$ and $240^{\circ}(\mathrm{SSW})$. This resulted in a reduction of cave air $p \mathrm{CO}_{2}$ by ca. 150 ppm (Fig. 6). During the first part of the night, wind speed was below $8 \mathrm{~km} \mathrm{~h}^{-1}$ and no disturbance could be detected in the cave. In the early hours of August 26, 2012, however, wind picked up again with speeds of 11 to $17 \mathrm{~km} \mathrm{~h}^{-1} \mathrm{from}$ directions of $190^{\circ}$ to $230^{\circ}$, again accompanied by a lowering of cave air $p \mathrm{CO}_{2}$ by around $100 \mathrm{ppm}$ (Fig. 6). After the wind direction changed westward and outside air was no longer pushed into the cave, the background ventilation reactivated.

In summary, the ventilation of the BEC System qualifies as dynamic in nature, with changes on seasonal to diurnal timescales. Chimney circulation is driven by air density differences forced by differential cave and outside air temperatures. This pattern is frequently overprinted by wind-induced air flow into the cave entrances. All of these factors make the Bunker-Emst Cave System an outstanding case example to highlight the forcing and interaction of multiple ventilation patterns.

\section{Implications for Speleothem Proxy Data}

The high resolution $\mathrm{pCO}_{2}$ monitoring was accompanied by placement of watch glasses $(\mathrm{U} \mathrm{I}, \mathrm{U} \mathrm{IV})$ under two drip sites (TS 1, TS 8). This was performed to assess carbonate precipitation dynamics in direct relation to ventilation 
A



$B$
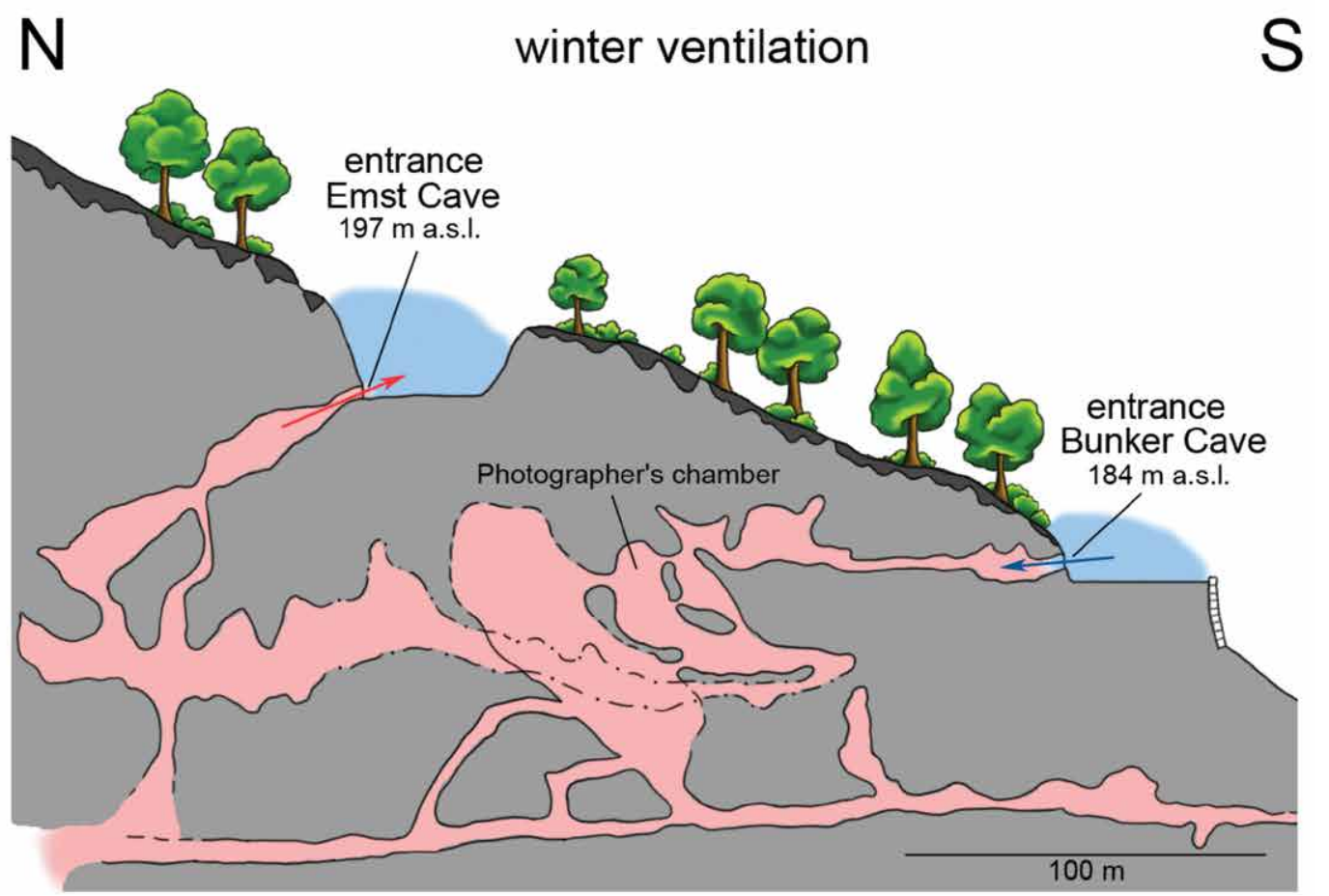

Figure 10. Schematic of winter and summer ventilation systematics. In summer, cave air is colder (blue) than outside air (red), and warm, less-dense outside air enters the upper entrance, to cool and descend, and exit through the lower entrance. During winter, outside air is colder (blue) than cave air (red). Thus, colder, denser, outside air flows through the lower entrance into the cave, warms up, ascends and flows out through the upper entrance. are relatively constant, which explains the especially stable precipitation rates at this site (Fig. 8). The very significant differences in calcite saturation and drip rate between both drip sites explains the equally significant differences in 
carbonate precipitation rates (Fig. 8). Carbon and oxygen isotope signatures of carbonate precipitates on both watch glasses depend on drip rate variability as previously shown (Riechelmann et al., 2013), but also seem to partly correspond with $\mathrm{pCO}_{2}$ variability (Fig. 9A). Drip rate differences between both drip sites (Fig. 8) are reflected in isotopic equilibrium in the case of site TS 1 / U I and isotopic disequilibrium at site TS 8 / UIV. Consequently, $\delta^{13} \mathrm{C}$ and $\delta^{18} \mathrm{O}$ are significantly higher in precipitates from site TS 8 / U IV (Fig. 9A; Riechelmann et al., 2013). Apparently, the modern range in seasonal $p \mathrm{CO}_{2}(\sim 400 \mathrm{ppmv})$ is too low to cause an observable change in calcite precipitation rates or isotopic composition on seasonal or annual timescales. Water supply (drip rate) and saturation $\left(\mathrm{SI}_{\text {calcite }}\right)$, rather, govern carbonate precipitation and isotopic fractionation of the recent watch glass precipitates (e.g., Dreybrodt, 1988, 2008; Fairchild and Baker, 2012). To apply these observations to speleothem proxy data, the carbon $(-6.09 \%)$ and oxygen $(-5.71 \%$ ) isotope values of the most recent part of speleothem BU 4 (located beneath drip site TS 8; Fig. 2) were compared with those of the precipitates on the corresponding watch glass U IV (mean $\delta^{13} \mathrm{C}:-5.92 \pm 0.72 \%$; mean $\delta^{18} \mathrm{O}:-5.54 \pm$ $0.26 \%$; Fig. 9A). Because these values are similarly within error, watch glass carbonate precipitates and speleothem carbonate are directly comparable. We conclude that the subdued modern $p \mathrm{CO}_{2}$ variability in the BEC System has little, if any, influence on speleothem precipitation rate or isotopic composition. Consequently, speleothem proxy records at this site are probably not significantly controlled by $\mathrm{CO}_{2}$ variations, but are rather more sensitive to temperature and rainfall shifts.

The artificial opening of both entrances in 1860-1863 and 1926, respectively, changed the ventilation dynamics of the BEC System, and the modern ventilation system is not analogous to the pre-1860-time interval. The opening of an entrance (naturally or artificially) to a cave without a natural entrance leads to immediate ventilation to adjust gradients between surface and cave, and likely to a rapid drop in cave air $\mathrm{pCO}_{2}$. This results in higher speleothem precipitation rates and an increase in $\delta^{13} \mathrm{C}$ values (Baldini et al., 2006). In analogy, stalagmite BU 4 displays a strong increase of $\sim 2$ $\%$ in $\delta^{13} \mathrm{C}$ over the last 150 years (Fig. 9B), which fits well with the opening of the first entrance in 1860-1863 (Emst Cave; Fohlmeister et al. 2012). Carbon isotope values in subsamples of speleothem calcite prior to this event are consistently lower (mean: $-8.85 \pm 0.85$; Fohlmeister et al., 2012). This suggests that during the Holocene, no large, natural entrance existed to facilitate ventilation. We suggest that without major entrances to the cave system during the Holocene, ventilation was minimal and $\mathrm{pCO}_{2}$ values were significantly higher and relatively stable. Precipitation rates found for BEC system stalagmites, which record decadal rather than annual or seasonal scale climate conditions, are mostly low, but comparable to carbonate precipitation rates of recent watch glass precipitates (Fohlmeister et al., 2012). Therefore, the precipitation rate of speleothem calcite is apparently unaffected by the opening of the cave entrances. Winterly water supply and higher saturation indices of calcite are, without much doubt, the two factors regulating past speleothem growth in the BEC System and not $p \mathrm{CO}_{2}$. This fact would lead to a climate signal biased toward the winter season as observed today. Although $\mathrm{pCO}_{2}$ variations, driven by the pre- and post-1860 ventilation patterns, have no influence on speleothem growth and isotopic composition, the artificial opening of the Bunker-Emst Cave System represents a particularly instructive example of the influence of changes in ventilation dynamics on speleothem proxy data.

\section{Conclusions}

The present-day ventilation patterns in the Bunker-Emst Cave System are mostly driven by air density (temperature) differences between cave and outside air. The resulting chimney circulation drives $p \mathrm{CO}_{2}$ variability in the cave. Ventilation direction changes seasonally. During winter, air flow from the lower to the upper entrance takes place, while in summer, the opposite air movement prevails. In spring and autumn, ventilation switches between these two patterns. Wind pressure, driving outside air into the southward-facing cave entrances, affects and overrides the density-driven chimney circulation. Sources of cave air $\mathrm{CO}_{2}$ include mostly outside air and, to smaller fractions, soil air and possibly even ground air. Under present-day conditions, the low variability of $\mathrm{pCO}_{2}$ in the BEC System does not affect speleothem precipitation rate, or the isotopic composition of carbonate precipitates, as documented by recent watch glass precipitates. Rather, speleothems are more sensitive to shifts in temperature and rainfall. The opening of the two artificial entrances in 1860-1863 and 1926, respectively, most likely led, to a shift in the ventilation patterns of the Bunker-Emst Cave System, with changes from seasonal to diurnal scale, relative to its pre-1860 state. This change in ventilation dynamics had a significant impact on speleothem carbon isotopes, which show a strong increase in their values. We suggest that during the Holocene, no comparably large access routes to the cave existed, and that prior to the opening of artificial entrances, cave air circulation was strongly reduced. Speleothem calcite precipitated prior to cave entrance opening suggests that $p \mathrm{CO}_{2}$ levels were significantly higher than today. The Bunker-Emst Cave System represents an exceptional natural laboratory that enables us to study recent ventilation patterns, as well as the transition from a natural to an anthropogenically-altered system and related shifts in speleothem isotope proxy data. Lessons learned here have wider significance for studies dealing with cave ventilation in general. 


\section{Acknowledgements}

This work received funding by the German Science Foundation (DFG) Research Group 668 (DAPHNE). We would like to thank the Speleogroup Letmathe for their support in monitoring Bunker Cave, and the student assistants F. T. Meyer and M. Lyhs are thanked for their help during the monitoring tours. We thank J. Schug (Meteogroup) for providing the data of the meteorological station Hemer. We thank editor M. Field and D. Tremaine, D. Mattey and one anonymous reviewer for their constructive and detailed comments on our manuscript.

\section{References}

Atkinson, T.C., 1977, Carbon dioxide in the atmosphere of the unsaturated zone: an important control of groundwater hardness in limestones: Journal of Hydrology, v. 35, p. 111-123. https://doi.org/10.1016/0022-1694(77)90080-4.

Bakalowicz, M., 2012, Epikarst. in Culver, D.C., eds., Encyclopedia of Caves (Second Edition): Academic Press, p. $284-288$.

Baldini, J.U.L., 2010, Cave atmosphere controls on stalagmite growth rate and paleoclimate Records, in Pedley, H. M., and Rogerson, M., eds., Tufas and speleothems: Unravelling the microbial and physical controls: Geological Society London, Special Publications 336, p. $283-294$.

Baldini, J.U.L., Bertram, R.A., and Ridley, H.E., 2018, Ground air: A first approximation of the Earth's second largest reservoir of carbon dioxide gas: Science of the Total Environment, v. 616-617, p. 1007-1013. https://doi.org/10.1016/j.scitotenv.2017.10.218.

Baldini, J.U.L., Baldini, L.M., McDermott, F., and Clipson, N., 2006, Carbon dioxide sources, sinks, and spatial variability in shallow temperate zone caves: Evidence from Ballynamintra Cave, Ireland: Journal of Cave and Karst Studies, v. 68, no. 1, p. 4-11.

Baldini, J.U.L., McDermott, F., Hoffmann, D.L., Richards, D.A., and Clipson, N., 2008, Very high-frequency and seasonal cave atmosphere pCO variability: Implications for stalagmite growth and oxygen isotope-based paleoclimate records: Earth and Planetary Science Letters, v. 272, p. 118-129. https://doi.org/10.1016/j.epsl.2008.04.031.

Banner, J.L., Guilfoyle, A., James, E.W., Stern, L.A., and Musgrove, M., 2007, Seasonal variations in modern speleothem calcite growth in central Texas, U.S.A.: Journal of Sedimentary Research, v. 77, p. 615-622. https://doi.org/10.2110/jsr.2007.065.

Benavente, J., Vadillo, I., Carrasco, F., Soler, A., Liñán, C., and Moral, F., 2010, Air carbon dioxide contents in the vadose zone of a Mediterranean karst: Vadose Zone Journal, v. 9, p. 126-136. https://doi.org/10.2136/vzj2009.0027.

Bender, M.M., 1971, Variations in the ${ }^{13} \mathrm{C} /{ }^{12} \mathrm{C}$ ratios of plants in relation to the pathway of photosynthetic carbon dioxide fixation: Phytochemistry, v. 10, p. 1239-1244. https://doi.org/10.1016/S0031-9422(00)84324-1.

Bögli, A., 1978, Karsthydrographie und physische Speläologie, Environmental Geology: Heidelberg, Springer, 292 p. https://doi.org/10.1007/9783-662-08051-1.

Breecker, D.O., Payne, A.E., Quade, J., Banner, J.L., Ball, C.E., Meyer, K.W., and Cowan, B.D., 2012, The sources and sinks of CO in caves under mixed woodland and grassland vegetation: Geochimica et Cosmochimica Acta, v. 96, p. 230-246. https://doi.org/10.1016/j. gca.2012.08.023.

Breitenbach, S.F.M., Lechleitner, F.A., Meyer, H., Diengdoh, G., Mattey, D., and Marwan, N., 2015, Cave ventilation and rainfall signals in dripwater in a monsoonal setting - a monitoring study from NE India: Chemical Geology, v. 402, p. 111-124. https://doi.org/10.1016/j.chemgeo.2015.03.011.

Cowan, B.D., Osborne, M.C., and Banner, J.L., 2013, Temporal variability of cave-air $\mathrm{CO}_{2}$ in Central Texas: Journal of Cave and Karst Studies, v. 75, no. 1, p. 38-50. https://doi.org/10.4311/2011ES0246.

Czuppon, G., Demény, A., Leél-Össy, S., Óvari, M., Molnár, M., Stieber, J., Kiss, K., Kármán, K., Surányi, G., and Haszpra, L., 2018, Cave monitoring in the Béke and Baradla caves (Northeastern Hungary): implications for the conditions for the formation cave carbonates: International Journal of Speleology, v. 47, p. 13-28. https://doi.org/10.5038/1827-806X.47.1.2110,

De Freitas, C. R., Littlejohn, R. N., Clarkson, T. S., and Kristament, I.S., 1982, Cave climate: Assessment of airflow and ventilation: International Journal of Climatology, v. 2, p. 383-397. https://doi.org/10.1002/joc.3370020408.

Domínguez-Villars, D., 2012, Heat flux, in Fairchild, I.J., and Baker, A., eds., Speleothem science: From process to past environments: Chichester, Wiley-Blackwell, p. 137-145.

Dreybrodt, W., 1988, Processes in Karst Systems_Physics, Chemistry and Geology, Berlin, Springer, 288 p. https://doi.org/10.1007/978-3-64283352-6.

Dreybrodt, W., 2008, Evolution of the isotopic composition of carbon and oxygen in a calcite precipitating $\mathrm{H}_{2} \mathrm{O}-\mathrm{CO}_{2}-\mathrm{CaCO}_{3}$ solution and the related isotopic composition of calcite in stalagmites: Geochimica et Cosmochimica Acta, v. 72, p. 4712-4724. https://doi.org/10.1016/j. gca.2008.07.022.

DWD (Deutscher Wetterdienst), 2013a, Pressemitteilung-Deutschlandwetter im März 2013, https://www.dwd.de/DE/presse/pressemitteilungen/ DE/2013/20130328_DeutschlandwetterimMaerz.pdf?_blob=publicationFile\&v=3 [accessed December 11, 2017].

DWD (Deutscher Wetterdienst), 2013b, Pressemitteilung-Deutschlandwetter im Juli 2013, https://www.dwd.de/DE/presse/pressemitteilungen/ DE/2013/20130730_DeutschlandwetterimJuli.pdf?_blob=publicationFile\&v=3 [accessed December 11, 2017].

Ek, C., and Godissart, J., 2014, Carbon dioxide in cave air and soil air in some karstic areas of Belgium. A prospective view: Geologica Belgica, v. 17 , no. 1 , p. 102-106.

Fairchild, I. J., and Baker, A., 2012, Speleothem science: From Process to Past Environments, Blackwell Quaternary Geoscience Series: Chichester, Wiley-Blackwell, 432 p. https://doi.org/10.1002/9781444361094.

Fohlmeister, J., Schröder-Ritzrau, A., Scholz, D., Spötl, C., Riechelmann, D.F.C., Mudelsee, M., Wackerbarth, A., Gerdes, A., Riechelmann, S., Immenhauser, A., Richter, D.K., and Mangini, A., 2012, Bunker Cave stalagmites: an archive for central European Holocene climate variability: Climate of the Past, v. 8, p. 1751-1764. https://doi.org/10.5194/cp-8-1751-2012.

Geiger, R., 1961, Das Klima der bodennahen Luftschicht, Braunschweig, Vieweg \& Sohn, 640 p.

German Federal Environmental Agency, 2018, Luftmessnetz des Umweltbundesamts: www.umweltbundesamt.de/themen/luft/messenbeobachtenueberwachen/luftmessnetz-des-umweltbundesamtes [accessed July 31, 2018].

Glaser, B., 2005, Compound-specific stable-isotope $\left(\delta^{13} \mathrm{C}\right)$ analysis in soil science: Journal of Plant Nutrition and Soil Science, v. 168, p. 633-648. https://doi.org/10.1002/jpln.200521794

Grebe, W., 1993, Die Bunkerhöhle in Iserlohn-Letmathe (Sauerland): Mitt. Verb. dt. Höhlen- und Karstforsch., v. 39, no. 2, p. $22-23$.

Gregorič, A., Vaupotič, J., and Šebela, S., 2014, The role of cave ventilation in governing cave air temperature and radon levels (Postojna Cave, Slovenia): International Journal of Climatology, v. 34, no. 5, p. 1488-1500. https://doi.org/10.1002/joc.3778. 
Hammerschmidt, E., Niggemann, S., Grebe, W., Oelze, R., Brix, M. R., and Richter, D. K., 1995, Höhlen in Iserlohn: Schriften zur Karst- und Höhlenkunde in Westfalen, v. 1, p. 153.

Henderson, G. M., 2006, Caving in to new chronologies: Science, v. 313, p. 620-622.

Hendry, M. J., and Wassenaar, L.I., 2005, Origin and migration of dissolved organic carbon fractions in a clay-rich aquitard: ${ }^{14} \mathrm{C}$ and $\delta^{13} \mathrm{C}$ evidence. Water Resources Research, v. 41, p. W02021.

James, J.M., 1977, Carbon dioxide in the cave atmosphere, in Transactions of the British Cave Research Association 4, p. 417-429

Keeling, C. D., Piper, S. C., Bacadtow, R.B., Wahlen, M., Whorf, T.P., Heimann, M., Meijer, H.A., 2005, Atmospheric $\mathrm{CO}_{2}$ and ${ }^{13} \mathrm{CO}_{2}$ exchange with the terrestrial biosphere and oceans from 1978 to 2000: Observations and carbon cycle implications, in Baldwin, I.T., Caldwell, M.M., Heldmaier, G., Jackson, R.B., Lange, O.L., Mooney, H. A., Schulze, E.D., Sommer, U., Ehleringer, J.R., Denise Dearing, M., Cerling, T.E., eds., A History of Atmospheric $\mathrm{CO}_{2}$ and Its Effect on Plants, Animals, and Ecosystems: Springer, p. 83-113.

Lauer, W., and Bendix, J., 2006, Klimatologie, Das Geographische Seminar: Braunschweig, Westermann, 352 p.

Lechleitner, F.A., Baldini, J.U.L., Breitenbach, S.F.M., Fohlmeister, J., Mclntyre, C., Goswami, B., Jamieson, R.A., van der Voort, T.S., Prufer, K., Marwan, N., Culleton, B.J., Kennett, D.J., Asmerom, Y., Polyak, V., and Eglinton, T.I., 2016, Hydrological and climatological controls on radiocarbon concentrations in a tropical stalagmite: Geochimica et Cosmochimica Acta, v. 194, p. 233-252. https://doi.org/10.1016/j. gca.2016.08.039.

Luetscher, M., and Ziegler, F., 2012, CORA: a dedicated device for carbon dioxide monitoring in cave environments: International Journal of Speleology, v. 41, no. 2, p. 275-283. https://doi.org/10.5038/1827-806X.41.2.13.

Madhavan, S., Treichel, I., and O'Leary, M.H., 1991, Effects of relative humidity on carbon isotope fractionation in plants: Botanica Acta, v. 104, p. 292-294. https://doi.org/10.1111/j.1438-8677.1991.tb00232.x.

Mattey, D.P., Latin, J.P., and Ainsworth, M., 2008, Cave monitoring and calibration of a $\delta^{18} \mathrm{O}$-climate transfer function for a Gibraltar speleothem: PAGES News, v. 16, p. 15-17. https://doi.org/10.22498/pages.16.3.15.

Mattey, D.P., Fairchild, I.J., Atkinson, T.C., Latin, J.-P., Ainsworth, M., and Durell, R., 2010, Seasonal microclimate control of calcite fabrics, stable isotopes and trace elements in modern speleothem from St. Michaels Cave, Gibraltar, in Pedley, H.M., and Rogerson, M., eds., Tufas and speleothems: Unravelling the microbial and physical controls: Geological Society, London, Special Publications 336, p. 323-344. https://doi. org/10.1144/SP336.17.

Mattey, D.P., Atkinson, T.C., Barker, J.A., Fisher, R., Latin, J.P., Durrell, R., and Ainsworth, M., 2016, Carbon dioxide, ground air and carbon cycling in Gibraltar karst: Geochimica et Cosmochimica Acta, v. 184, p. 88-113. https://doi.org/10.1016/j.gca.2016.01.041.

McDonough, L.K., Iverach, C.P., Beckmann, S., Manefield, M., Rau, G.C., Baker, A., and Kelly, B.F. J., 2016, Spatial variability of cave-air carbon dioxide and methane concentrations and isotopic compositions in a semi-arid karst environment: Environmental Earth Sciences, v. 75, p. 700. https://doi.org/10.1007/s12665-016-5497-5.

Miorandi, R., Borsato, A., Frisia, S., Fairchild, I.J., and Richter, D.K., 2010, Epikarst hydrology and implications for stalagmite capture of climate changes at Grotta di Ernesto (NE Italy): results from long-term monitoring: Hydrological Processes, v. 24, p. 3101-3114. https://doi. org/10.1002/hyp.7744.

Noronha, A.L., Johnson, K. R., Southon, J.R., Chaoyong Hu, Jiaoyang Ruan, McCabe-Glynn, S., Radiocarbon evidence for decomposition of aged organic matter in the vadose zone as the main source of speleothem carbon: Quaternary Science Reviews, v. 127, p. 37-47. https://doi. org/10.1016/j.quascirev.2015.05.021.

O'Leary, M.H., 1988, Carbon isotopes in photosynthesis: Fractionation techniques may reveal new aspects of carbon dynamics in plants: BioScience, v. 38, p. 328-336. https://doi.org/10.2307/1310735.

Peel, M.C., Finlayson, B.L., and McMahon, T.A., 2007, Updated world map of the Köppen-Geiger climate classification: Hydrology and Earth System Sciences, v. 11, p. 1633-1644. https://doi.org/10.5194/hess-11-1633-2007.

Pla, C., Cuezva, S., Garcia-Anton, E., Fernandez-Cortes, A., Cañaveras, J.C., Sanchez-Moral, S., and Benavente, D., 2016, Changes in the CO dynamics in near-surface cavities under a future warming scenario: Factors and evidence from the field and experimental findings: Science of The Total Environment, v. 565, p. 1151-1164. https://doi.org/10.1016/j.scitotenv.2016.05.160.

Pollak, H.N., and Shaopeng Huang, 2000, Climate reconstruction from subsurface temperatures: Annual Review of Earth and Planetary Science, v. 28, p. 339-365. https://doi.org/10.1146/annurev.earth.28.1.339.

Junbing Pu, Aoyu Wang, Licheng Shen, Jianjan Yin, Daoxian Yuan, and Heping Zhao, 2016, Factors controlling the growth rate, carbon and oxygen isotope variation in modern calcite precipitation in a subtropical cave, Southwest China: Journal of Asian Earth Sciences, v. 119, p. 167-178. https://doi.org/10.1016/j.jseaes.2015.12.010.

Ridley, H.E., Baldini, J.U.L., Prufer, K.M., Walczak, I.W., and Breitenbach, S.F.M., 2015, High-resolution monitoring of Yok Balum Cave, Belize: An investigation of seasonal ventilation regimes and the atmospheric and drip-flow response to a local earthquake: Journal of Cave and Karst Studies, v. 77, no.3, p. 183-199. https://doi.org/10.4311/2014ES0117.

Riechelmann, D.F.C., Schröder-Ritzrau, A., Scholz, D., Fohlmeister, J., Spötl, C., Richter, D.K., and Mangini, A., 2011, Monitoring Bunker Cave (NW Germany): A prerequisite to interpret geochemical proxy data of speleothems from this site: Journal of Hydrology, v. 409, no. 3-4, p. 682-695. https://doi.org/10.1016/j.jhydrol.2011.08.068.

Riechelmann, D.F.C., Deininger, M., Scholz, D., Riechelmann, S., Schröder-Ritzrau, A., Spötl, C., Richter, D.K., Mangini, A., and Immenhauser, A., 2013, Disequilibrium carbon and oxygen isotope fractionation in recent cave calcite: Comparison of cave precipitates and model data: Geochimica et Cosmochimica Acta, v. 103, p. 232-244. https://doi.org/10.1016/j.gca.2012.11.002.

Riechelmann, S., Schröder-Ritzrau, A., Spötl, C., Riechelmann, D.F.C., Richter, D.K., Mangini, A., Frank, N., Breitenbach, S.F.M., and Immenhauser, A., 2017, Sensitivity of Bunker Cave to climatic forcings highlighted through multi-annual monitoring of rain-, soil-, and dripwaters: Chemical Geology, v. 449, p. 194-205. https://doi.org/10.1016/j.gca.2012.11.002

Riechelmann, S., Schröder-Ritzrau, A., Wassenburg, J.A., Schreuer, J., Richter, D.K., Riechelmann, D.F.C., Terente, M., Constantin, S., Mangini, A., and Immenhauser, A., 2014, Physicochemical characteristics of drip waters: Influence on mineralogy and crystal morphology of recent cave carbonate precipitates: Geochimica et Cosmochimica Acta, v. 145, p. 13-29. https://doi.org/10.1016/j.gca.2014.09.019.

Rossi, C., and Lozano, R.P., 2016, Hydrochemical controls on aragonite versus calcite precipitation in cave dripwaters: Geochimica et Cosmochimica Acta, v. 192, p. 70-96. https://doi.org/10.1016/j.gca.2016.07.021.

Smerdon, J.E., Pollack, H.N., Cermak, V., Enz, J.W., Kresl, M., Safanda, J., and Wehmiller, J.F., 2006, Daily, seasonal and annual relationships between air and subsurface temperatures: Journal of Geophysical Research, v. 111, p. D07101 https://doi.org/10.1029/2004JD005578.

Spötl, C., Fairchild, I.J., and Tooth, A F., 2005, Cave air control on dripwater geochemistry, Obir Caves (Austria): Implications for speleothem deposition in dynamically ventilated caves: Geochimica et Cosmochimica Acta, v. 69, no. 10, p. 2451-2468. https://doi.org/10.1016/j. gca.2004.12.009. 
Tremaine, D.M., Froelich, P.N., and Yang Wang, 2011, Speleothem calcite farmed in situ: Modern calibration of $\delta^{18} \mathrm{O}$ and $\delta^{13} \mathrm{C}$ paleoclimate proxies in a continuously-monitored natural cave system: Geochimica et Cosmochimica Acta, v. 75, p. 4929-4950. https://doi.org/10.1016/j. gca.2011.06.005.

Van Rampelbergh, M., Verheyden, S., Allan, M., Quinif, Y., Keppens, E., and Claeys, P., 2014, Monitoring of a fast-growing speleothem site from the Han-sur-Lesse cave, Belgium, indicates equilibrium deposition of the seasonal $\delta^{18} \mathrm{O}$ and $\delta^{13} \mathrm{C}$ signals in the calcite: Climate of the Past, $\mathrm{v}$. 10, p. 1871-1885. https://doi.org/10.5194/cp-10-1871-2014.

Wood, W.W., 1985, Origin of caves and other solution openings in the unsaturated (vadose) zone of carbonate rocks: $\mathrm{A}_{\text {model for }} \mathrm{CO}_{2}$ generation: Geology, v. 13, p. 822-824. https://doi.org/10.1130/0091-7613(1985)13\%3C822:OOCAOS\%3E2.0.CO;2. 